Article

\title{
Rational Design of a New Class of Toll-Like Receptor 4 (TLR4) Tryptamine Related Agonists by Means of the Structure- and Ligand-Based Virtual Screening for Vaccine Adjuvant Discovery
}

\author{
Jan Honegr ${ }^{1,2}$ (D), Rafael Dolezal ${ }^{1,3,4}$, David Malinak ${ }^{1,3}{ }^{\text {, Marketa Benkova }}{ }^{1}$ (D), \\ Ondrej Soukup $^{1}$ (D), Joyce S. F. D. de Almeida ${ }^{5}$, Tanos C. C. Franca ${ }^{4,5}$ (D), Kamil Kuca ${ }^{1,2}$ \\ and Roman Prymula ${ }^{1, *}$ \\ 1 Biomedical Research Centre, University Hospital Hradec Kralove, Sokolska 581, \\ 50005 Hradec Kralove, Czech Republic; jan.honegr@gmail.com (J.H.); rafael.dolezal@fnhk.cz (R.D.); \\ david.malinak@gmail.com (D.M.); marketa.pasdiorova@fnhk.cz (M.B.); ondrej.soukup@fnhk.cz (O.S.); \\ kamil.kuca@fnhk.cz (K.K.) \\ 2 Department of Forensic Medicine and Intensive Medicine, Faculty of Medicine, University of Ostrava, \\ Syllabova 19, Ostrava 70300, Czech Republic \\ 3 Department of Chemistry, Faculty of Science, University of Hradec Kralove, Rokitanskeho 62, \\ 50003 Hradec Kralove, Czech Republic \\ 4 Center for Basic and Applied Research, Faculty of Informatics and Management, University of Hradec Kralove, \\ Rokitanskeho 62, 50003 Hradec Kralove, Czech Republic; tanosfranca@gmail.com \\ 5 Laboratory of Molecular Modeling Applied to Chemical and Biological Defense, \\ Military Institute of Engineering, Praca General Tiburcio 80, Rio de Janeiro 22290-270, Brazil; \\ joycesfdalmeida@gmail.com \\ * Correspondence: prymula@fnhk.cz; Tel.: +420-495-833-447
}

Received: 18 December 2017; Accepted: 29 December 2017; Published: 4 January 2018

\begin{abstract}
In order to identify novel lead structures for human toll-like receptor 4 ( $h$ TLR4) modulation virtual high throughput screening by a peta-flops-scale supercomputer has been performed. Based on the in silico studies, a series of 12 compounds related to tryptamine was rationally designed to retain suitable molecular geometry for interaction with the $h$ TLR4 binding site as well as to satisfy general principles of drug-likeness. The proposed compounds were synthesized, and tested by in vitro and ex vivo experiments, which revealed that several of them are capable to stimulate $h$ TLR4 in vitro up to $25 \%$ activity of Monophosphoryl lipid A. The specific affinity of the in vitro most potent substance was confirmed by surface plasmon resonance direct-binding experiments. Moreover, two compounds from the series show also significant ability to elicit production of interleukin 6 .
\end{abstract}

Keywords: PRR; TLR4; innate immunity; virtual screening; molecular dynamics; adjuvants

\section{Introduction}

In recent years, we are experiencing outbreaks of epidemics of diseases like measles or rubeola against which we already have preventive vaccines [1]. It must be said that such outbreaks occur mainly in the so called "Western world", and are caused by anti-systemic paranoia, conspiratorial theorists or just individuals who want to make their profit out of uninformed people. One of the biggest issues with vaccination is mainly their administration in small children or even newborns, which makes parents extremely sensitive when giving anything potentially harmful to their beloved ones [2].

One of the core beliefs, besides that vaccines causes autism, is that vaccines contain dangerous adjuvants like mercury, aluminium, squalene, animal cells, formaldehyde and many other suspicious 
substances [3]. Such opinions are partially true because preparation of actual vaccines is a multi-step process requiring various agents and tools. It is undeniable that most vaccines contain alum, or that thiomersal is used in the early stages of the manufacturing process of some vaccines, or directly added to anti-influenza vaccines (e.g., Pandermix) [4]. On the other hand, it has been proved beyond any doubt by a vast number of studies [5] that mercury or aluminium in vaccines do not cause autism or behavioral problems like attention deficit disorder (ADHD). Despite this fact, claims that vaccines are generally not safe sometimes come from unexpected, but highly influential sources like the Court of Justice of the European Union [6]. This is the reason why development of novel vaccines containing safer adjuvants is necessary.

Other factors complicating the willingness for application of vaccines are a worldwide focus on the health safety, and limitation of their adverse effect potential. This leads to the development of novel types of subunit, or DNA vaccines, which are much safer than traditional attenuated or killed vaccines, but in the same time they are not as effective in eliciting strong and long-lasting protection [7]. This is caused by lack of naturally adjuvanting compounds that innate immunity system recognize as danger associated molecular patterns (DAMPs). The most potent ones is the endotoxin, also known as lipopolysaccharide (LPS), constituted by the polymeric complex moiety which is found in the outer membrane of Gram-negative bacteria, and which is responsible for eliciting very strong immune responses in animals [8].

LPS is recognized in organisms by divergent biochemical pathways. One pathway uses natural antibodies and lipoproteins to neutralize and clear LPS. The second pathway triggers a vigorous and complex inflammatory response involving activation of immunocompetent cells (such as monocytes, macrophages, and hepatic Kupffer cells) through lipopolysaccharide binding protein (LBP), cell surface-bound protein coded by the cluster of differentiation 14 gene (CD14), and toll-like receptor 4 (TLR4). TLR4 activation by bacterial LPS is achieved by the coordinate and sequential action of three other proteins, the lipopolysaccharide binding protein (LBP), the cluster differentiation antigen CD14, and the myeloid differentiation protein (MD2) receptors. The three receptors bind the LPS and present it in a monomeric form to the TLR4 by forming the activated dimer ( $h$ TRL4/MD2-LPS) ${ }_{2}$ complex. Identification of LPS triggers the complex regulatory cascade, leading to the production of pro-inflammatory cytokines (IL-1, TNF- $\alpha$, IL-6, IL-8 etc.) that can protect the host. [9]

LPS is a highly toxic substance causing septic shock and septicaemia, thus, efforts in diminishing of its toxic properties have been made. It was found that the part mainly responsible for the immunogenic properties of LPS is the so-called Lipid A. Later, a derivative of Lipid A-Monophosphoryl lipid A (MPLA) has been introduced as a vaccine adjuvant. However, the complexity of MPLA urges rational design of simpler compounds that retain intrinsic activity on $h$ TRL4/MD2 and are easier to prepare and handle $[9,10]$.

In the present study we focused on rational design of novel $h$ TRL4/MD2 modulators employing virtual high throughput screening (vHTPS) with the use of a peta-flops-scale super computer [11]. From several promising substances identified in this in silico study, we have selected a chemical structure (VS) which exhibited considerable in silico binding affinity towards $h$ TRL4/MD2 model (i.e., binding energy estimate of $-14.3 \mathrm{kcal} / \mathrm{mol}$ ) (Figure 1). This compound can be found in the online ZINC database under code ZINC02157367.

In order to optimize drug-like properties of the hit structure VS indicated by virtual screening and to keep, to certain extent, its main structural features responsible for the interactions with $h$ TRL4/MD2 in the same time, a novel structure LS was designed with the aim to achieve especially a lower lipophilicity (Figure 2). 


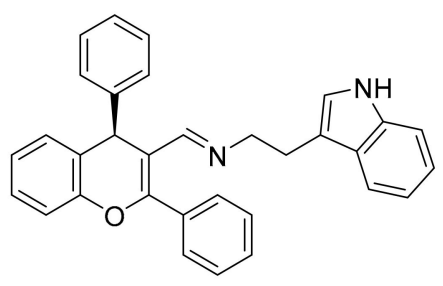

VS

$-14.3 \mathrm{kcal} / \mathrm{mol}$

Figure 1. A hit structure VS selected by virtual high throughput screening and its predicted binding energy for $h$ TRL4/MD2 (PDB ID: 4G8A).<smiles>C(=NCCc1c[nH]c2ccccc12)C1=C(c2ccccc2)Oc2ccccc2[C@H]1c1ccccc1</smiles>

VS

$\log P=6.80$<smiles>O=C(NCCc1c[nH]c2ccccc12)c1ccccc1</smiles>

LS

Figure 2. Optimization of the VS hit structure identified by virtual screening to less lipophilic lead structure LS. The $\log P$ values were calculated in MarvinSketch 15.12.7.0.

Therefore, the first objective of the present work was to design 12 novel structures related to $N$-(2-(1H-indol-3-yl)ethyl)benzamide (LS), to predict their affinity for $h$ TRL4/MD2 by flexible molecular docking and molecular dynamics. At second, the practical part of the work involved synthesis and testing of the compounds by in vitro and ex vivo experiments to confirm the predicted properties.

\section{Results and Discussion}

\subsection{Virtual Screening and Rational Design}

In this study, we have performed a combined ligand and structure based virtual screening of 130,000 compounds using a peta-flops-scale supercomputer to find novel potential modulators of $h$ TRL4/MD2 (PDB ID: 4G8A). This hierarchical in silico methodology consisted in a ligand based virtual screening of a random virtual library containing 130,000 structures from the ZINC database (http://zinc.docking.org/), $\mathrm{MW} \leq 500, x \log \mathrm{p} \leq 7, \mathrm{HBD} \leq 5$, and $\mathrm{HBA} \leq 10$. Using known $h$ TRL4/MD2 agonists and antagonists as templates (e.g., carbamazepine, fentanyl, morphine, loverphaol, ibudilast, naloxone, etc.), 9700 structures were selected from the starting database, having a Tanimoto similarity index with respect to the template structures higher than 0.7 . Another 300 structures were chosen from our in-house compound library and from the literature [10,12-17]. In total, 10,000 structures were submitted to flexible molecular docking in AutoDock Vina 1.1.2. to estimate their binding energy in $h$ TRL4/MD2 (PDB ID: 4G8A). Since the computational demands for the structure-based virtual screening required roughly 500,000 core-hours, the Anselm supercomputer was used (IT4Innovations, National Supercomputing Center, http://www.it4i.cz). From the top scoring candidates, we selected the structure VS, which exhibited very promising estimate of the binding energy in $h$ TRL4/MD2. Taking into account that the vast majority of biochemical experiments needs water soluble substances, an intuitive design of VS was made to achieve a structure with a 
lower lipophilicity. Investigating the predicted binding mode of VS, we simplified the hit structure to N-(2-(1H-indol-3-yl)ethyl)benzamide (LS, Figure 2), which retains the tryptamine moiety to interact with Phe151 in the active site of $h$ TRL4/MD2 (PDB ID: 4G8A) and is capable to bind by its phenyl ring with Phe76 or Phe104 (Figure 3).

These structural requirements for ligands to bind in mostly hydrophobic active site of $h$ TRL4/MD2 were considered together along with general principles of rational drug design, which recommend to follow for instance the classical Lipinski's rule of five. The structure LS was proposed to exhibit sufficient affinity towards $h$ TRL4/MD2 as well to be more water soluble and easily synthesizable. Based on these ideas, 12 different compounds related to LS were designed, analyzed by flexible molecular docking in hTRL4/MD2, synthesized and tested by in vitro and ex vivo experiments. Finally, the observed in vitro activities of the synthesized compounds in $h$ TRL4/MD2 were compared with the results of molecular dynamic simulations which provided optimized binding energy estimates by Poisson-Boltzmann surface area continuum solvation method (MM/PBSA).

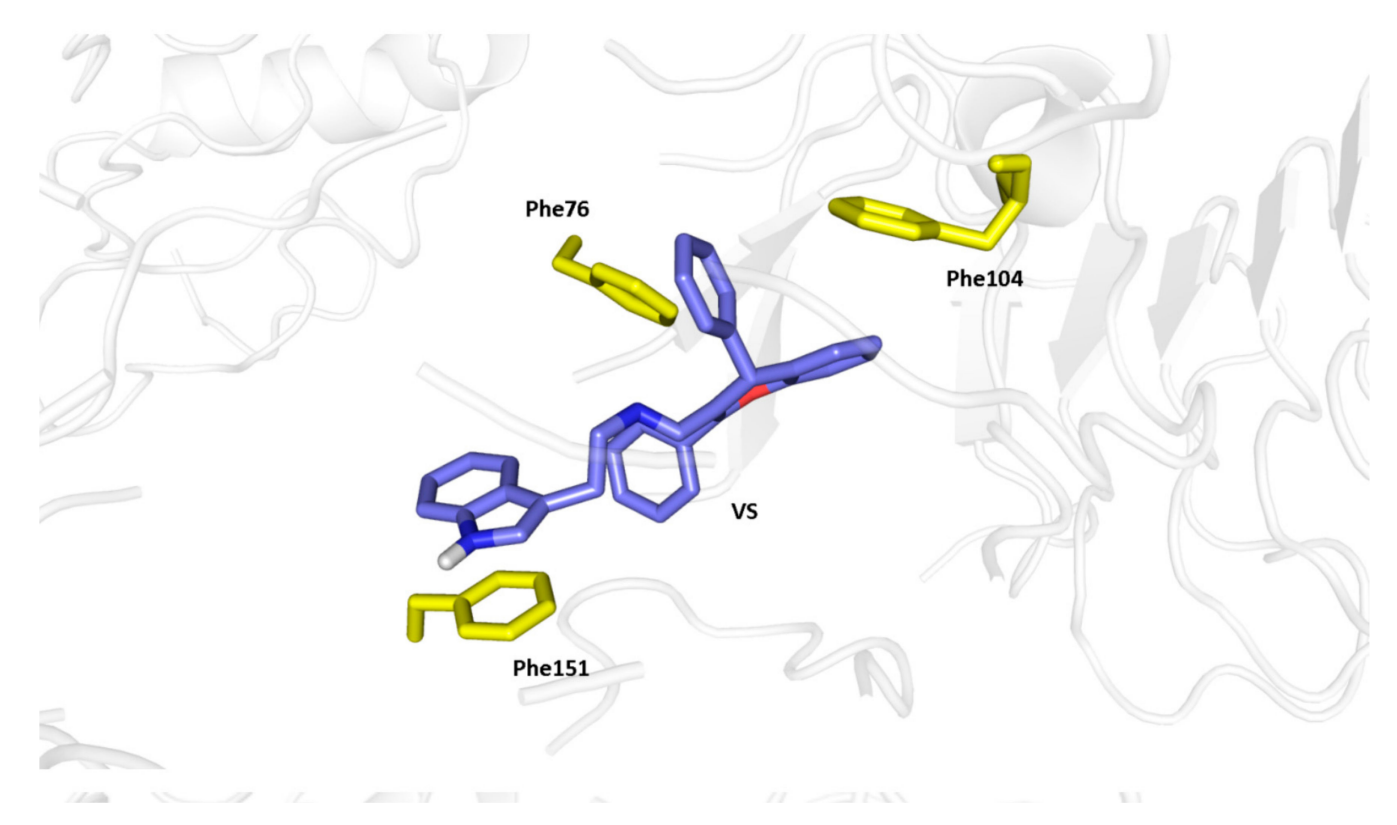

Figure 3. Binding mode of VS in $h$ TRL4/MD2 (PDB ID: 4G8A) determined by structure-based virtual screening. The carbon atoms of the ligand are colored in blue, the aminoacid residues are colored in yellow.

\subsection{Chemistry}

The compounds 14-25 were synthesized by two different procedures (A and B). In this work both previously synthesized tryptamine derivatives 14-20 [18-25] and new tryptamine derivatives 21-25 have been prepared. Products 14-21 were prepared by nucleophilic acyl substitution of tryptamine (1) by the commercially available acyl chlorides $\mathbf{2}-\mathbf{9}$. The reactions were carried out in $\mathrm{CH}_{2} \mathrm{Cl}_{2}$ in the presence of $\mathrm{Et}_{3} \mathrm{~N}$ as the base. Reaction yields were in the range 59-92\% (Scheme 1) (Procedure A).

In the procedure $\mathrm{B}$, the appropriate acyl chlorides were first prepared in situ by reaction of commercially available carboxylic acids 10-13 with $(\mathrm{COCl})_{2}$ and a catalytic amount of $\mathrm{DMF}$ in $\mathrm{CH}_{2} \mathrm{Cl}_{2}$. Subsequently, nucleophilic acyl substitution of compound 1 by the prepared acyl chlorides in $\mathrm{CH}_{2} \mathrm{Cl}_{2}$ in the presence of $\mathrm{Et}_{3} \mathrm{~N}$ as the base provided final products 22-25 in 81-91\% yields after two steps (Scheme 2). The course of all reactions was monitored by TLC, and the structures of all products after column chromatography purification were determined by ${ }^{1} \mathrm{H}-,{ }^{13} \mathrm{C}-\mathrm{NMR}$ and HRMS analysis. The melting points were also determined for the characterization of the synthesized compounds 
14-25 (Table 1). Based on LC with UV detection $(\lambda=254 \mathrm{~nm})$, the non-calibrated purity of final products was $\geq 95 \%$.

\subsection{Molecular Docking Study}

The interactions of 14-25 compounds with $h$ TRL4/MD2 (PDB ID: 4G8A) were simulated by flexible molecular docking using AutoDock Vina 1.1.2 software [26]. The active site for the in silico study was determined by the position of LPS co-crystalized with the receptor, involving all the residues within a sphere of $R=10 \AA$ centered in the geometrical center of LPS into the flexible docking part of the receptor. The binding energies between the ligands and $h$ TRL4/MD2 calculated by the flexible molecular docking AutoDock Vina 1.1.2 are summarized in Figure 4.
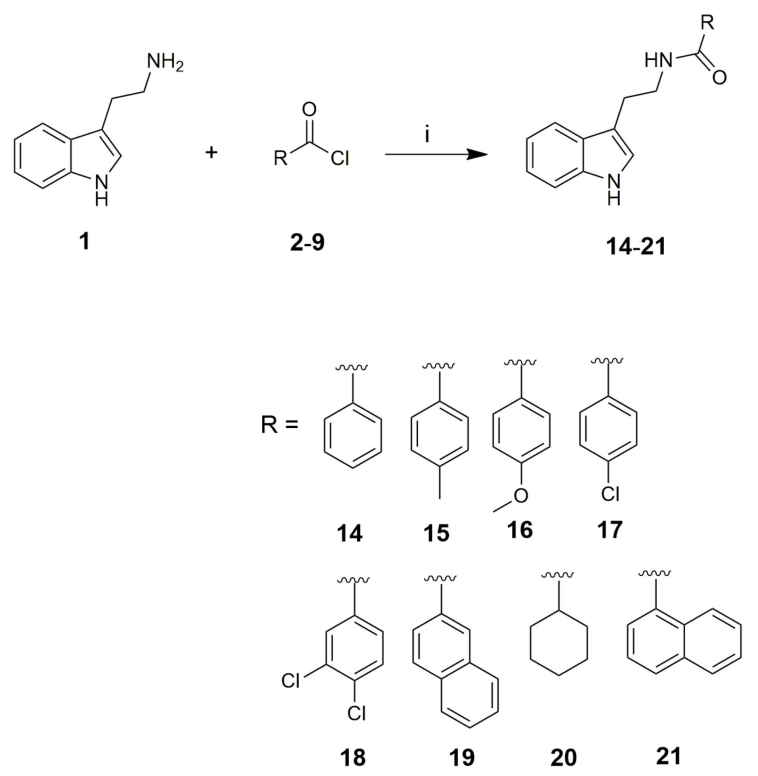

Scheme 1. Synthesis of compounds 14-21 (Procedure A). Reagents and conditions: (i) $\mathrm{Et}_{3} \mathrm{~N}, \mathrm{CH}_{2} \mathrm{Cl}_{2}$, $0{ }^{\circ} \mathrm{C} \rightarrow$ r.t., 1 h, $59-92 \%$.<smiles>[R]C(=O)NCCc1c[nH]c2ccccc12</smiles>

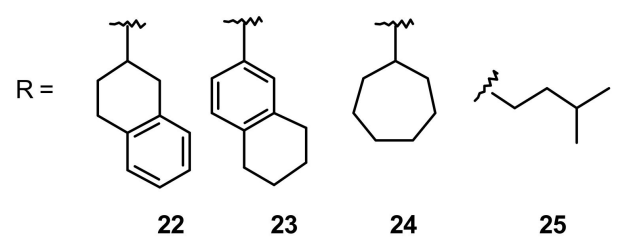

Scheme 2. Synthesis of compounds 22-25 (Procedure B). Reagents and conditions: (i) $(\mathrm{COCl})_{2}, \mathrm{DMF}$, carboxylic acids $10-13, \mathrm{CH}_{2} \mathrm{Cl}_{2}, 0^{\circ} \mathrm{C} \rightarrow$ r.t., $1 \mathrm{~h}$; (ii) $\mathrm{Et}_{3} \mathrm{~N}, \mathrm{CH}_{2} \mathrm{Cl}_{2}, 0^{\circ} \mathrm{C} \rightarrow$ r.t., $1 \mathrm{~h}, 81-91 \%$. 
Table 1. Yields and melting points of compounds 14-25.

\begin{tabular}{clcc}
\hline Compound & \multicolumn{1}{c}{$\mathbf{R}$} & Yield (\%) & m.p. $\left({ }^{\circ} \mathbf{C}\right)$ \\
\hline $\mathbf{1 4}$ & Phenyl & $81^{\mathrm{a}}$ & $141.2-142.8$ \\
$\mathbf{1 5}$ & 4-(Methyl)phenyl & $92^{\mathrm{a}}$ & $126.8-128.2$ \\
$\mathbf{1 6}$ & 4-(Methoxy)phenyl & $87^{\mathrm{a}}$ & $132.8-134.3$ \\
$\mathbf{1 7}$ & 4-(Chloro)phenyl & $66^{\mathrm{a}}$ & $150.6-152.0$ \\
$\mathbf{1 8}$ & 3,4-(Dichloro)phenyl & $75^{\mathrm{a}}$ & $112.4-113.9$ \\
$\mathbf{1 9}$ & 2-Naphtyl & $92^{\mathrm{a}}$ & $193.2-195.0$ \\
$\mathbf{2 0}$ & Cyclohexyl & $59^{\mathrm{a}}$ & $104.8-106.3$ \\
$\mathbf{2 1}$ & 1-Naphtyl & $80^{\mathrm{a}}$ & $164.5-166.5$ \\
$\mathbf{2 2}$ & 1,2,3,4-Tetrahydro-2-naphtyl & $81^{\mathrm{b}}$ & $123.2-125.2$ \\
$\mathbf{2 3}$ & 5,6,7,8-Tetrahydro-2-naphtyl & $91^{\mathrm{b}}$ & $137.0-139.0$ \\
$\mathbf{2 4}$ & Cycloheptyl & $90^{\mathrm{b}}$ & $88.4-90.4$ \\
$\mathbf{2 5}$ & Isopentyl & $87^{\mathrm{b}}$ & $45.1-47.1$ \\
\hline
\end{tabular}

a Yield of reaction of acyl chloride with tryptamine (Procedure A); ${ }^{\text {b }}$ Yield of reaction of carboxylic acid with tryptamine (Procedure B).

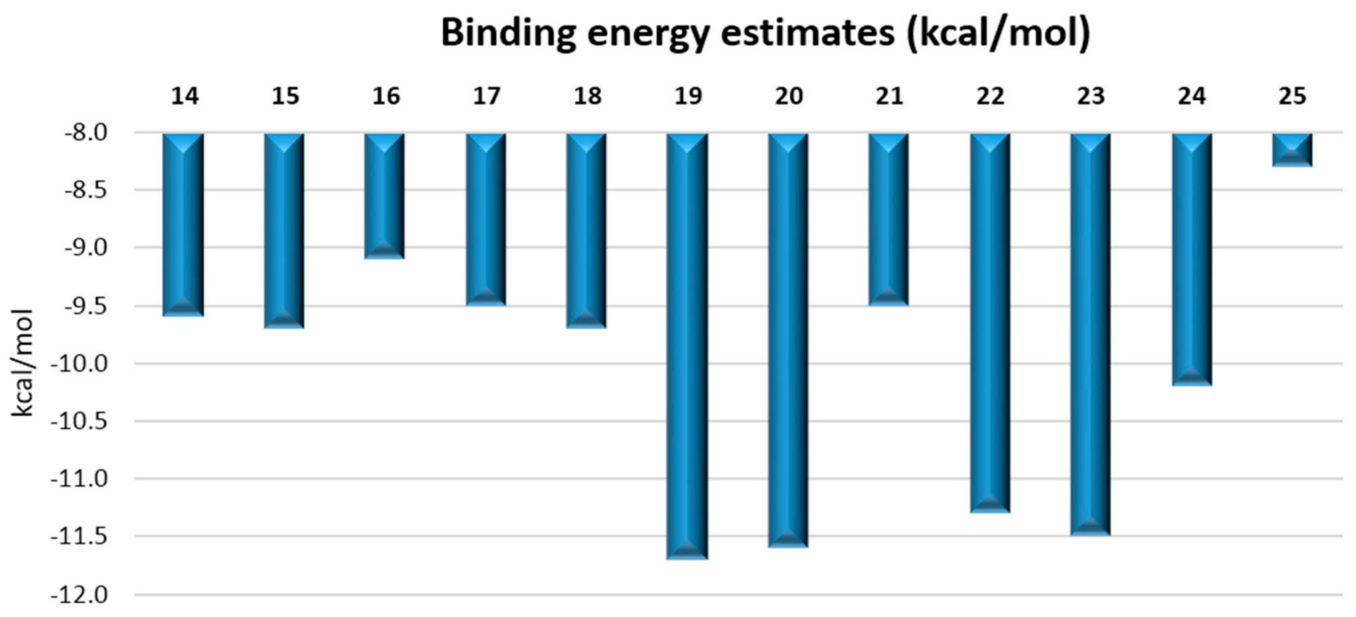

Figure 4. Binding energy estimates of 14-25 for $h$ TRL4/MD2-LPS (PDB ID: 4G8A) determined by flexible molecular docking.

As can be seen from Figure 4, the top-scoring binding energies were predicted for compounds 19, 20, 22 and 23, which may be due to their naphtyl or tetrahydronapthyl moieties exhibiting relatively stronger interactions in mostly lipophilic active site of $h$ TRL4/MD2. Nonetheless, the best in vitro agonistic activity for $h$ TRL4/MD2 receptor was shown by compound 17 containing 4-chlorophenyl moiety, giving the molecule a lower lipophilicity in comparison to 19 or 21.

Molecular modeling revealed that $\mathbf{1 7}$ is predominantly stabilized in the $h$ TRL4/MD2 active site by weak interactions with aromatic residues (Figure 5). The indolyl moiety of $\mathbf{1 7}$ interacts by T-shaped $\pi-\pi$ coupling with Phe104 (3.8 $\AA$ ) and this ligand part is additionally anchored in the position by Ile63 (4.4 $\AA$ ). The 4-chlorophenyl function in the second molecular part of $\mathbf{1 7}$ is involved in a slightly shifted $\pi-\pi$ stacking with Phe151 (3.9 $)$ ). From the physico-chemical point of view, these interactions, characterized by the calculated Gibbs energy of $-9.5 \mathrm{kcal} / \mathrm{mol}$, seems to be rather weak. However as we discovered in this study, the in silico binding energy of LPS to $h$ TRL4/MD2 is even lower, $-8.7 \mathrm{kcal} / \mathrm{mol}$, although it elicits very strong agonistic response from the receptor. Another active site residues in $h$ TRL4/MD2 are located in a longer distance from $\mathbf{1 7}$ and they are not considered as significantly contributing to the complex stabilization. 


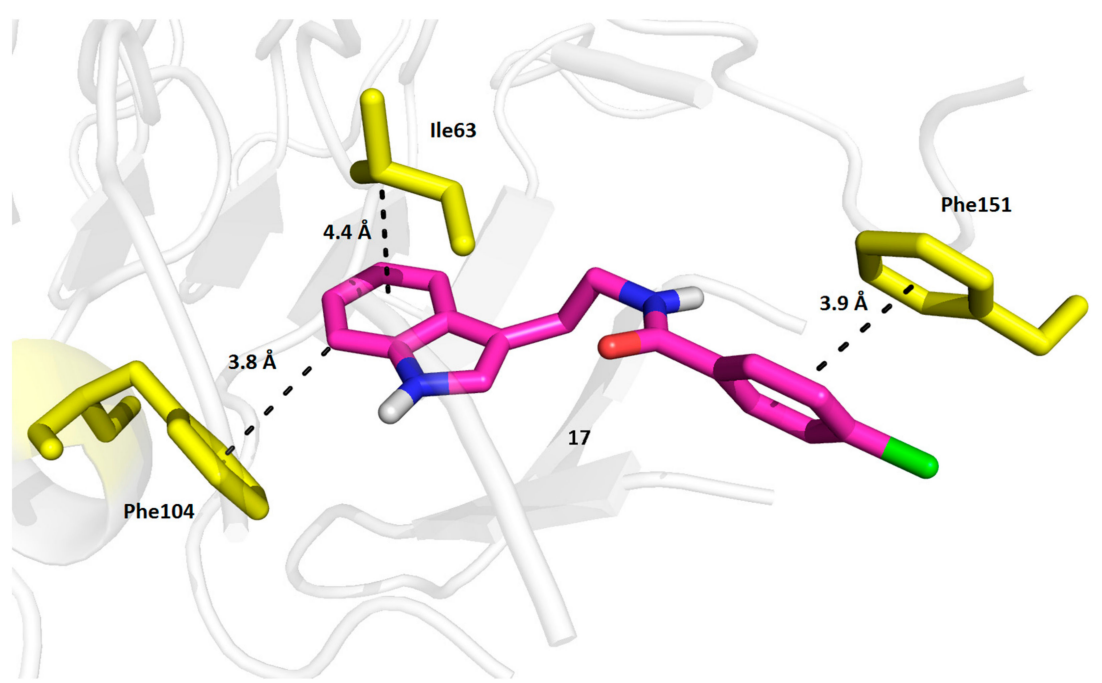

(A)

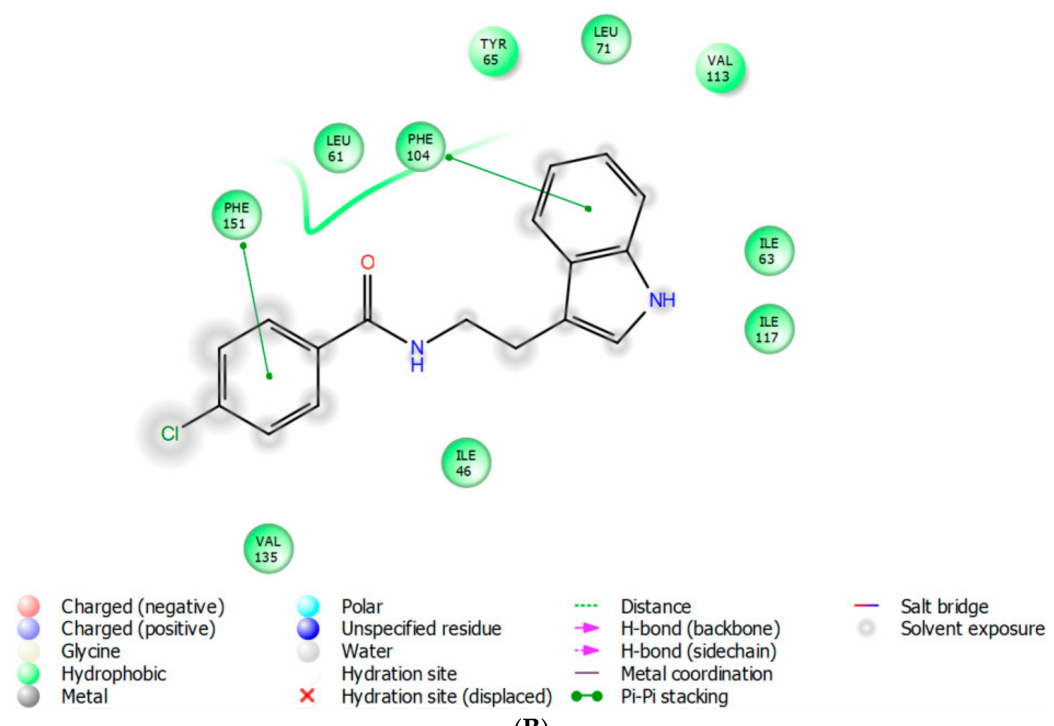

(B)

Figure 5. Biding mode of compound 17 in $h$ TRL4/MD2 (PDB ID: 4G8A) obtained by flexible molecular docking; (A) 3D visualization (The carbon atoms of the ligand are colored in magenta, the aminoacid residues are colored in yellow); (B) 2D model.

\subsection{Molecular Dynamic Study}

In order to evaluate the binding modes and binding energy estimates obtained by flexible molecular docking in AutoDock Vina 1.1.2, a molecular dynamic study (MD) was performed in Gromacs 5.1.2 using OPLSAA force field. Accelerated performance in the MD study was achieved by applying a supercomputer equipped with computing nodes with 16 CPUs (Intel Xeon E5-2470) and 1 GPU (NVIDIA Tesla K20m). Using a self-developed bash script we carried out 10 ns simulations of all the 12 ligand-protein complexes in water. The hTRL4/MD2 (PDB ID: 4G8A) model with the docked ligands were paremetrized by Topobuild 1.3 program, hydrated in a dodecahedron solvent box, neutralized by $\mathrm{Na}^{+} / \mathrm{Cl}^{-}$ions as appropriate and geometrically optimized by the steepest descent algorithm. Then, these ligand-receptor complexes were simulated for $10 \mathrm{~ns}$ at $300 \mathrm{~K}$ in a parallel calculation mode. The obtained MD trajectories and binary input files (i.e., xtc and tpr files) were adjusted by trjconv function, sampled with $250 \mathrm{ps}$ frequency, and subsequently analyzed by g_mmpbsa software to obtain the binding free energy estimates by MM/PBSA method $[27,28]$. The obtained energies are summarized in Table 2. 
Table 2. Mean binding energies and their standard sample deviations for 14-25 in $h$ TRL4/MD2 (PDB ID: 4G8A) estimated by MM/PBSA method from 10 ns MD simulations.

\begin{tabular}{cccc}
\hline Compound & Predicted Binding Energy $\mathbf{( k c a l / m o l )}$ & Compound & Predicted Binding Energy (kcal/mol) \\
\hline $\mathbf{1 4}$ & $-23.454 \pm 5.368$ & $\mathbf{2 0}$ & $-19.255 \pm 4.028$ \\
$\mathbf{1 5}$ & $-20.059 \pm 6.248$ & $\mathbf{2 1}$ & $-19.344 \pm 6.022$ \\
$\mathbf{1 6}$ & $-21.144 \pm 4.535$ & $\mathbf{2 2}$ & $-21.381 \pm 4.511$ \\
$\mathbf{1 7}$ & $-22.874 \pm 3.929$ & $\mathbf{2 3}$ & $-18.090 \pm 3.767$ \\
$\mathbf{1 8}$ & $-21.288 \pm 3.531$ & $\mathbf{2 4}$ & $-23.696 \pm 2.684$ \\
$\mathbf{1 9}$ & $-20.495 \pm 4.284$ & $\mathbf{2 5}$ & $-18.361 \pm 2.846$ \\
\hline
\end{tabular}

All the resulting MD trajectories were visually checked whether the ligand-receptor complexes are stably bonded during the simulations. In all the complexes, generally stable interactions were observed, which is illustrated by the average RMSDs for the ligands fluctuating between $0.064-0.186 \mathrm{~nm}$. It seems that larger values of RMSD for the ligand conformations are associated with larger deviations of the MM/PBSA binding energies, but it is important to take into consideration that the ligand-receptor complex can move as a whole, which leads to an increased RMSD for ligands, while the complex can stay stable. In Supporting Information, overlaid ligand conformations obtained in the MD simulations are given (frames sampled with frequency of 25 ps (Figures S14-S25)). From the MD simulations, it was also obvious that the MD2 domain, which is not covalently bounded to the TLR4 domain, can move in some cases slightly further from the starting position (e.g., for 21). Such structural changes may have significant impact on $h$ TLR4/MD2 dimerization, and, consequently, on eliciting the agonistic receptor response. The strongest binding energy within the MD study was calculated for $\mathbf{2 4 , 1 4}$ and $\mathbf{1 7}$ (a record of the MD simulation for $\mathbf{1 7}$ is given in Supporting Information (Video 1)). In comparison with the binding energies predicted by molecular docking, compounds $\mathbf{1 9}$ and 20 did not exhibit so strong interactions with hTRL4/MD2 in the MD study. Nonetheless, the MM/PBSA binding energies seem to be closer to the experimental data, although the correct ranking of compounds according to their in vitro activities for $h$ TLR4/MD2 cannot be achieved by these MM/PBSA energies.

\subsection{Cytotoxicity, In Vitro and Ex Vivo Effects}

The toxicity was estimated on the cell cultures in order to exclude the most toxic motifs from further development and to test whether the compounds might be used in the functional cell-model of TLR4. Standard MTT assay (Sigma Aldrich, Damrstadt, Germany) was applied according to the manufacturer's protocol on the CHO-K1 (Chinese hamster ovary, ECACC, Salisbury, UK).

The $\mathrm{IC}_{50}$ values were calculated from the control-subtracted triplicates using non-linear regression (four parameters) of GraphPad Prism 5 software (GraphPad Software, La Jolla, CA, USA). Final IC 50 and SEM value was obtained as a mean of 2-3 independent measurements (see Table 3). The results clearly shows that our compounds' cytotoxic effect is relatively low $\left(\mathrm{IC}_{50}\right.$ ranging from $98-892 \mu \mathrm{M}$, thus they can be used in subsequent experiments using $h$ TL4R4/MD2 cell model (Section 2.6).

Table 3. Cytotoxicity evaluation.

\begin{tabular}{cc}
\hline Compound & IC $_{\mathbf{5 0}}$ and SEM $(\boldsymbol{\mu M})$ \\
\hline $\mathbf{1 4}$ & $297 \pm 17$ \\
$\mathbf{1 5}$ & $197 \pm 41$ \\
$\mathbf{1 6}$ & $200 \pm 7$ \\
$\mathbf{1 7}$ & $201 \pm 8$ \\
$\mathbf{1 8}$ & $892 \pm 122$ \\
$\mathbf{1 9}$ & $155 \pm 12$ \\
$\mathbf{2 0}$ & $211 \pm 43$ \\
$\mathbf{2 2}$ & $128 \pm 8$ \\
$\mathbf{2 3}$ & $98 \pm 6$ \\
$\mathbf{2 4}$ & $170 \pm 10$ \\
$\mathbf{2 5}$ & $348 \pm 35$ \\
\hline
\end{tabular}




\subsection{In Vitro Activity for hTLR4/MD2}

We have tested each of the newly-synthesized compound at $10 \mu \mathrm{M}(10 \%$ of lowest cytotoxic $\mathrm{IC}_{50}$, see Section 2.5) for an internal activity on a cell line stably expressing the $h \mathrm{TLR} 4 / \mathrm{MD} 2$ receptor and found that compound $\mathbf{1 7}$ reaches more than $20 \%$ and Compound $\mathbf{2 2}$ approximately showed $10 \%$ activity of MPLA (Figure 6). Compounds 24 and 25 weren't evaluated due to stability issues of the compounds (unwanted degradations from crystals to amorphous state). Thus we have provide a proof of concept of the $h$ TLR4/MD2 agonists' rational design and by that we have revealed, until now unknown class of ligands, which has promising intrinsic activity and are easily synthesizable.

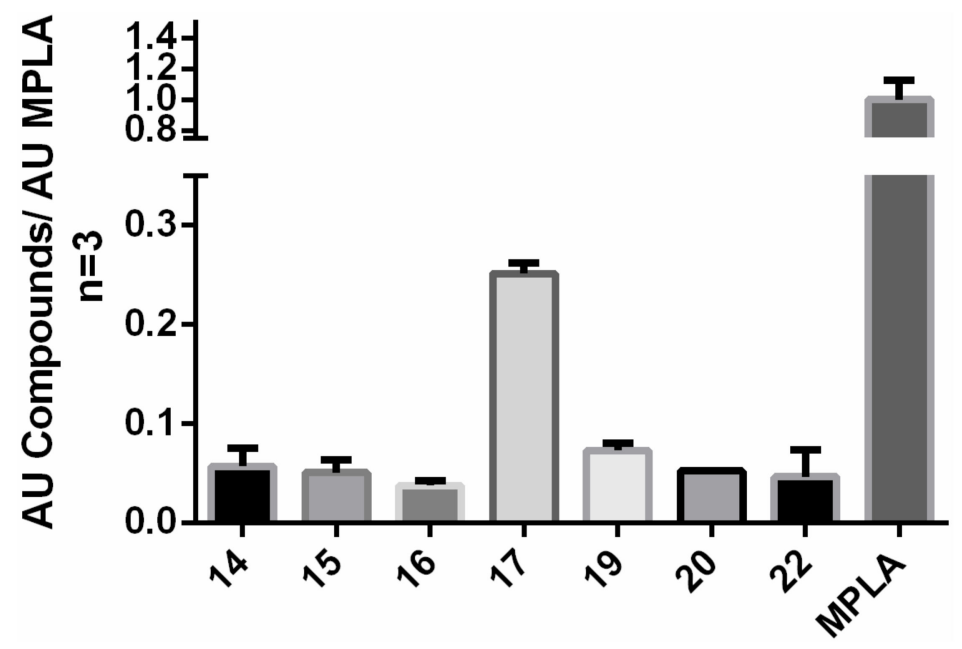

Figure 6. $h$ TLR4/MD2 in vitro evaluation. Values normalized to the activity of MPLA expressed as the Mean \pm standard error of mean $(n=3)$. For conditions see the experimental section.

\subsection{Surface Plasmon Resonance (SPR)}

To shed light on the prediction capabilities of vHTPS, direct binding of the best compound from the in vitro study (17) to the $h$ TRL4/MD2 complex was investigated through Biospecific Interaction Analysis using the SPR-based biosensor Biacore T200 (GE Healthcare, Little Chalfont, UK). Recombinant $h$ TRL4/MD2 complex (R\&D Systems, Abingdon, UK) was immobilized on the chip, and the direct binding to the $h$ TRL4/MD2 complex was confirmed (Figure 7).

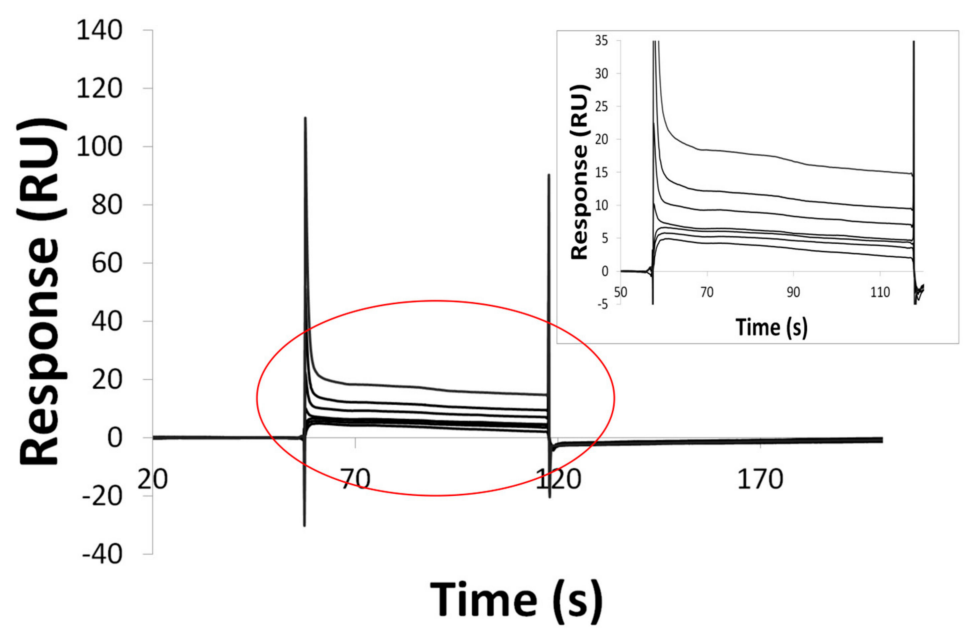

Figure 7. SPR experiment-Binding of compound $\mathbf{1 7}$ to the chip with immobilized $h$ TRL4/MD2 complex. Compound 17 was injected at concentrations from 6.25 to $200 \mu \mathrm{M}$ (from bottom to the top -inset represents same data on magnified scale for better discernibility). 
We think that it is reasonable to suggest, because of the similarity of presented compounds, that all other compounds are interacting with the hTRL4/MD2 complex in a similar way. Compound 17 was further analyzed using a series of concentrations from 6.25 up to $200 \mu \mathrm{M}$ (binary dilution). The clear dose-response binding of compound 17 was observed (Figure 7), with rapid dissociation rates. $K_{D}$ was determined at $7.47 \times 10^{-7} \mathrm{M}$.

\subsection{Ex Vivo Stimulation of IL-6 Production}

Important factor in adjuvants development is wheter the compounds are capable to elicit immune response not only on reporter cells but on real immunocompetent cels. We have chosen ex vivo study on human Periferal blood mononuclear cells (PBMCs) to evaluate the ability to produce an interleukin 6 (IL-6). IL-6 plays critical role in the innate imunity possessing both pro and anti-inflamatory properties. We have collected the blood samples from healthy donors. From those blood samples we had harvested PBMCs by standard protocol using Histopaque 1077 density gradient. PBMC specimens were frozen and kept in liquid nitrogen. The cells were incubated for $24 \mathrm{~h}$ with $10 \mu \mathrm{M}(10 \%$ of lowest cytotoxic $\mathrm{IC}_{50}$ - see the Sections 2.5 and 2.6) of each compound and the ability to elicit IL-6 production was assessed. Synthetic MPLA (MPLAs) in equimolar concentration (10 $\mu \mathrm{M})$ was used as a positive control and LPS from Rhodobacter sphaeroides $100 \mathrm{ng} / \mathrm{mL}$ (LPS-RS) as a negative control. IL-6 production was quantified by ELISA commercial kit (Sigma Aldrich) and results were interpreted by GraphPad Prism using Nonlinear Fit of RIA data function. We observed, that the Compounds 14 and 22 were able to significantly induce production of IL-6 which is in line with the in-silico prediction. On the other hand hit compound from the in vitro study (17) did not shown any effect on the IL-6 production. Effect on other pro-inflamatory cytokines (e.g., IL-1) was not determined in this study and will be subject of ongoing study in order to explain discrepancy among in silico, in vitro and ex vivo findings. Furthermore study evaluating the influence of compounds on Th1/Th2/Th17 bias will be needed to thoroughly assess their adjuvant and immunomodulating potential. Nevertheless, despite such necesarry and laborious tasks novel TLR4 agonists and potential vaccine adjuvants have been found.

The results are sumarized in Table 4 . All the experiment were approved by the Ethical Committee and informed consent was obtained from all subjects (healthy volounteers).

Table 4. Ex vivo stimulation of IL-6 production.

\begin{tabular}{cc}
\hline Compound & $\mathrm{c}(\mathrm{pg} / \mathrm{mL})$ \\
\hline $\mathbf{1 4}$ & 53.501 \\
$\mathbf{1 5}$ & - \\
$\mathbf{1 6}$ & - \\
$\mathbf{1 7}$ & - \\
$\mathbf{1 8}$ & - \\
$\mathbf{1 9}$ & - \\
$\mathbf{2 0}$ & - \\
$\mathbf{2 2}$ & 147.64 \\
LPS-RS & - \\
MPLA & 3078.97 \\
\hline
\end{tabular}

\section{Experimental Section}

\subsection{Virtual Screening}

In this study a combined ligand and structure based virtual screening with utilization of a peta-flops-scale supercomputer (www.it4i.cz) has been performed to reveal promising hit structures able to modulate $h$ TLR4/MD2 receptor (PDB ID: 4G8A). In the first stage, a random selection of 130,000 compounds having $\mathrm{MW} \leq 500, x \log \mathrm{p} \leq 7, \mathrm{HBD} \leq 5$, and $\mathrm{HBA} \leq 10$ was downloaded from the online ZINC database and processed in Screening Assistant 2 program. From this custom virtual ligand library, 9700 structures exhibiting Tanimoto similarity index higher than 0.7 towards carbamazepine, fentanyl, morphine, oxycodone, morphine-3-glucuronide, levorphanol, buprenorphine, oxcarbazepine, 
ethanol, pethidine, methadone, mianserin, imipramine, eritoran, cyclobenzaprine, naltrexone, ibudilast, ketotifen, propentofylline, amitriptyline, naloxone were selected. Additional 300 ligands were obtained from our in house compound database or designed according to the literature [10,12-17]. In total, 10,000 ligands were submitted to structure-based virtual screening by flexible molecular docking.

In structure based virtual screening, a 3D X-ray model of $h$ TLR4/MD2 (PDB ID: 4G8A), resolution: $2.4 \AA$ ) was downloaded from the online PDB database (http://www.rcsb.org/) and prepared for molecular docking by MGL Tools utilities. The model $h$ TLR4/MD2 (PDB ID: 4G8A) was engineered by Ohto et al. to correct three mutations (ASP299 to GLY299, THR399 to ILE399, and ARG56 to GLY56) [29]. The preparation of the receptor involved removal of the surplus copies of the enzyme chains, water molecules, non-bonded inhibitors and cofactors, addition of polar hydrogens and merging of non-polar ones. Default Gasteiger charges were assigned to all the atoms. The flexible part of the $h$ TLR4/MD2 receptor was determined by a spherical selection of residues $(R=11 \AA$ ) approximately around the geometrical center of the co-crystalized molecule of LPS ( $x=-14.925, y=-19.741, z=-10.93)$, which corresponds to the center of the receptor binding site. In the same point the center of the grid box of $33 \times 33 \times 33 \AA$ was positioned. The rotatable bonds in the flexible residues were detected automatically by AutoDock Tools 1.5.4 program. The flexible receptor part contained 32 residues (VAL24, CYS25, ILE32, SER33, TYR34, ILE46, VAL48, CYS51, ILE52, GLU53, LEU54, SER57, LEU61, ILE63, PHE76, LEU78, ILE80, GLU92, PHE119, SER120, PHE121, PHE126, TYR131, LYS132, CYS133, VAL134, VAL135, LEU149, GLU150, PHE151, VAL152, ILE153).

The complete set of 10,000 ligands was protonized as appropriate for $\mathrm{pH}=7.4$ in OpenBabel 2.3.3 and converted into pdbqt format in AutoDock Tools 1.5.4 program in the same way as the flexible hTLR4/MD2 enzyme part. By means of a bash-based script for efficient parallelization, all the ligands were docked in hTLR4/MD2 using AutoDock Vina 1.1.2 program as a molecular docking engine. Basically, AutoDock Vina combines a Markov chain Monte Carlo like method for the global search and a Broyden-Fletcher-Goldfarb-Shano gradient approach for the local search [30]. It is a type of memetic algorithm based on interleaving stochastic and deterministic calculations [26,31]. Each molecular docking task was performed with the exhaustiveness parameter set to 16, employing 16 CPU in parallel multithreading. The top scoring candidates were chosen according to the minimum predicted Gibbs binding energy. The graphic representations of the docked poses were rendered in PyMOL 1.6. (The PyMOL Molecular Graphics System, Version 1.6. Schrödinger, LLC).

\subsection{Molecular Docking Study}

The receptor $h$ TLR4/MD2 (PDB ID: 4G8A) for flexible molecular docking in AutoDock Vina was prepared in the same way as mentioned in Section 3.1 on the virtual screening. The models of the newly prepared compounds 14-25 were firstly drawn in HyperChem 8.0 (HyperCube Inc., Gainesville, FL, USA), then manually protonated as suggested by MarvinSketch 6.2.0. software, geometrically optimized by semi-empirical quantum-chemistry PM3 method and stored as pdb files. The structures of these ligands were processed for docking in a similar way as the flexible parts of the $h$ TLR4/MD2 receptor by AutoDock Tools 1.5.4 program. The same setting molecular docking (i.e., gridbox parameters) as in the virtual screening was applied. Each docking task was repeated 10 times with the exhaustiveness parameter set to 16 , employing 16 CPU in parallel multithreading. From the obtained results, the solutions reaching the minimum predicted Gibbs binding energy were taken as the top-scoring modes. The graphic representations of the docked poses were rendered in PyMOL 1.6 (Schroedinger, Manheim, Germany), 2D diagrams were generated using Maestro 10.1 (Schroedinger, Manheim, Germany).

\subsection{Molecular Dynamics}

MM/PBSA binding energies of the ligand-receptor complexes (14-25), obtained in the molecular docking study, were predicted employing molecular dynamic simulations in Gromacs 5.1.2 and g_mmpbsa software. All the chemical structures were parameterized by means of OPLSAA force 
field in Topobuild 1.3. program). Each molecular system contained the $h$ TLR4/MD2 (PDB ID: 4G8A) with the docked compounds, water molecules (SPC/E, single point charge), and $\mathrm{Na}^{+} / \mathrm{Cl}^{-}$ions to neutralize the total charge in a dodecahedron body shape. Then the systems were minimized by the steepest descent algorithm to release any close contacts, equilibrated for 100 ps under canonical NVT conditions ( $\mathrm{N}$-number of particles, $\mathrm{V}$ - the system volume, $\mathrm{T}$-temperature) at $300 \mathrm{~K}$ and simulated for $10 \mathrm{~ns}$ under NPT (P-pressure) conditions at $300 \mathrm{~K}$. In the production MD run, the step of $2 \mathrm{fs}$, time constant of 0.1 ps with modified Berendsen thermostat, pressure coupling by a semi-isotropic Parrinello-Rahman barostat with the time constant of 2 ps and 1 bar reference pressure and holonomic constraints (i.e., LINCS algorithm) were applied. The neighbor list for the calculation of nonbonded interactions was updated every five time steps with the cutoff of $1.2 \mathrm{~nm}$. A twin range cutoff of $1.4 \mathrm{~nm}$ was used for both Coulomb and Lennard-Jones interactions. Particle Mesh Ewald (PME) method was used for the treatment of long-range electrostatic interactions.

The obtained MD trajectories were adjusted by trjconv and sampled to skip every 25 frames. These altered trajectory files were processed in g_mmpsa to calculate polar, apolar, and vacuum potential energy contributions to free binding energy estimates between the ligands and $h$ TLR4/MD2. The resulting data were next processed by MmPbSaStat.py script developed by Rashmi Kumari and Andrew Lynn (http:/ / rashmikumari.github.io/g_mmpbsa/) to obtain the binding energy estimates and their standard sample deviations. Using rmsdist subroutine in Gromacs, root mean square distances (RMSD) for the ligand movements in the complexes during the MD simulations were calculated. All the molecular dynamic and MM/PBSA calculations were carried out in supercomputers (www.it4i.cz) equipped with nodes containing 16 CPUs (Intel Xeon E5-2470, Intel) and 1 GPU (NVIDIA Tesla K20m).

\subsection{Chemistry General Methods}

All commercial reagents and dry solvents used were of the highest available purity from Sigma-Aldrich (Darmstadt, Germany). All reactions were performed under an atmosphere of nitrogen, unless otherwise noted. For flash column chromatography on silica gel, Kieselgel 60 (0.063-0.200 mm, 70-230 mesh, Fluka) was used. The solvents for column chromatography were purchased from Penta chemicals Co. (Prague, Czech Republic), and solvents for LC/MS analyses were obtained in LC-MS grade purity from Sigma-Aldrich (Darmstadt, Germany). Thin layer chromatography was run on silica gel $60 \mathrm{~F}_{254}$ analytical plates (Merck, Darmstadt, Germany); mobile phase: heptane/EtOAc 1/1; heptane/EtOAc 2/1); detection was carried out with ultraviolet light (254 nm). Melting points were recorded on a Stuart SMP30 Melting Point Apparatus (Cole-Parmer, Stone, UK) and are uncorrected. The ${ }^{1} \mathrm{H}$ NMR and ${ }^{13} \mathrm{C}$ NMR spectra were recorded in DMSO- $d_{6}$ solution at ambient temperature on a S500 spectrometer (Varian, Palo Alto, CA, USA); $499.87 \mathrm{MHz}$ for ${ }^{1} \mathrm{H}$ and $125.71 \mathrm{MHz}$ for ${ }^{13} \mathrm{C}$ ). Chemical shifts, $\delta$, are given in parts per million (ppm), and spin multiplicities are given as s (singlet), $\mathrm{d}$ (doublet), $\mathrm{t}$ (triplet), or $\mathrm{m}$ (multiplet). Coupling constants, $J$, are expressed in hertz $(\mathrm{Hz})$. For ${ }^{1} \mathrm{H} \delta$ relative to DMSO- $d_{6}(\delta=2.50)$ and for ${ }^{13} \mathrm{C}$ relative to DMSO- $d_{6}(\delta=39.43)$. HRMS spectra were determined by $\mathrm{Q}$ Exactive Plus hybrid quadrupole-orbitrap spectrometer (ThermoFisher, Bremen, Germany).

3.4.1. General Procedure for Synthesis of Compounds 14-21 by Reaction of Commercially Available Acyl Chlorides with Tryptamine (Procedure A)

To the solution of tryptamine $(1,1.87 \mathrm{mM})$ in dry $\mathrm{CH}_{2} \mathrm{Cl}_{2}(8 \mathrm{~mL})$, that had been pre-cooled to $0{ }^{\circ} \mathrm{C}$, the $\mathrm{Et}_{3} \mathrm{~N}(3.74 \mathrm{mM})$ and acyl chloride $(\mathbf{2}-\mathbf{9}, 2.43 \mathrm{mM})$ were gradually added. The resulting mixture was stirred for $10 \mathrm{~min}$ at $0{ }^{\circ} \mathrm{C}$ and then at room temperature for a further $50 \mathrm{~min}$. The course of reactions was monitored by TLC. Subsequently the solvent was evaporated under vacuum and the residue was chromatographed on silica gel, eluent heptane-EtOAc (1:1) (for compounds 14-16) and heptane-EtOAc (2:1) (for compounds 17-21).

N-(2-(1H-Indol-3-yl)ethyl)benzamide (14). Compound 1 was treated with benzoyl chloride (2) according to the above procedure A to give the desired product 14 in the form of white crystals (81\%); m.p.: 
141.2-142.8 ${ }^{\circ} \mathrm{C} .{ }^{1} \mathrm{H}-\mathrm{NMR}\left(\mathrm{DMSO}-d_{6}\right) \delta 2.95-2.98\left(\mathrm{~m}, 2 \mathrm{H}, \mathrm{CH}_{2}\right), 3.54-3.58\left(\mathrm{~m}, 2 \mathrm{H}, \mathrm{CH}_{2}\right), 6.97-7.00$ (m, 1H, ArH), 7.06-7.09 (m, 1H, ArH), 7.18-7.19 (m, 1H, ArH), 7.35 (d, J = 8.1 Hz, 1H, ArH), 7.44-7.47 $(\mathrm{m}, 2 \mathrm{H}, 2 \times \mathrm{ArH}), 7.50-7.53(\mathrm{~m}, 1 \mathrm{H}, \mathrm{ArH}), 7.59(\mathrm{~d}, J=7.8 \mathrm{~Hz}, 1 \mathrm{H}, \mathrm{ArH}), 7.85-7.87(\mathrm{~m}, 2 \mathrm{H}, 2 \times \mathrm{ArH})$, $8.61(\mathrm{t}, J=5.5 \mathrm{~Hz}, 1 \mathrm{H}, \mathrm{NH}), 10.81(\mathrm{~s}, 1 \mathrm{H}, \mathrm{NH}) ;{ }^{13} \mathrm{C}-\mathrm{NMR}\left(\mathrm{DMSO}-d_{6}\right) \delta 25.10,40.12,111.27,111.81$, $118.12,118.19,120.81,122.50,127.02,127.19,128.13,130.90,134.62,136.15,166.01$ ppm. HRMS $\left(\mathrm{HESI}^{+}\right)$: $[\mathrm{M}+\mathrm{H}]^{+}$: calculated for $\mathrm{C}_{17} \mathrm{H}_{17} \mathrm{~N}_{2} \mathrm{O}^{+}(m / z)$ : 265.1335; found: 265.1331 .

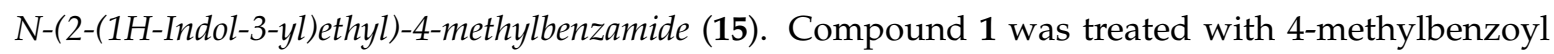
chloride (3) according to the above procedure A to give the desired product 15 in the form of a white crystals (92\%); m.p.: $126.8-128.2{ }^{\circ} \mathrm{C} .{ }^{1} \mathrm{H}-\mathrm{NMR}\left(\mathrm{DMSO}-d_{6}\right) \delta 2.35\left(\mathrm{~s}, 3 \mathrm{H}, \mathrm{CH}_{3}\right), 2.94-2.97\left(\mathrm{~m}, 2 \mathrm{H}, \mathrm{CH}_{2}\right)$, 3.52-3.57 (m, 2H, $\left.\mathrm{CH}_{2}\right), 6.97-7.00(\mathrm{~m}, 1 \mathrm{H}, \mathrm{ArH}), 7.06-7.09(\mathrm{~m}, 1 \mathrm{H}, \mathrm{ArH}), 7.18-7.19(\mathrm{~m}, 1 \mathrm{H}, \mathrm{ArH}), 7.26(\mathrm{~d}$, $J=8.1 \mathrm{~Hz}, 2 \mathrm{H}, 2 \times \mathrm{ArH}), 7.35(\mathrm{~d}, J=8.1 \mathrm{~Hz}, 1 \mathrm{H}, \mathrm{ArH}), 7.59(\mathrm{~d}, J=7.8 \mathrm{~Hz}, 1 \mathrm{H}, \mathrm{ArH}), 7.77(\mathrm{~d}, J=8.2 \mathrm{~Hz}$, $2 \mathrm{H}, 2 \times \mathrm{ArH}), 8.53(\mathrm{t}, J=5.6 \mathrm{~Hz}, 1 \mathrm{H}, \mathrm{NH}), 10.81(\mathrm{~s}, 1 \mathrm{H}, \mathrm{NH}) ;{ }^{13} \mathrm{C}-\mathrm{NMR}\left(\mathrm{DMSO}-d_{6}\right) \delta 20.83,25.15,40.08$, 111.26, 111.85, 118.11, 118.20, 120.81, 122.47, 127.04, 127.20, 128.65, 131.83, 136.15, 140.71, 165.89 ppm. HRMS $\left(\mathrm{HESI}^{+}\right)$: $[\mathrm{M}+\mathrm{H}]^{+}$: calculated for $\mathrm{C}_{18} \mathrm{H}_{19} \mathrm{~N}_{2} \mathrm{O}^{+}(m / z)$ : 279.1492; found: 279.1488 .

$\mathrm{N}-(2-(1 \mathrm{H}-\mathrm{Indol}-3-\mathrm{yl})$ ethyl)-4-methoxybenzamide (16). Compound 1 was treated with 4-methoxybenzoyl chloride (4) according to the above procedure $\mathrm{A}$ to give the desired product $\mathbf{1 6}$ in the form of a white crystals $(87 \%)$; m.p.: $132.8-134.3{ }^{\circ} \mathrm{C} .{ }^{1} \mathrm{H}-\mathrm{NMR}$ (DMSO- $\left.d_{6}\right) \delta 2.93-2.96\left(\mathrm{~m}, 2 \mathrm{H}, \mathrm{CH}_{2}\right), 3.51-3.55(\mathrm{~m}, 2 \mathrm{H}$, $\left.\mathrm{CH}_{2}\right), 3.81\left(\mathrm{~s}, 3 \mathrm{H}, \mathrm{OCH}_{3}\right), 6.97-7.01(\mathrm{~m}, 3 \mathrm{H}, 3 \times \mathrm{ArH}), 7.05-7.09(\mathrm{~m}, 1 \mathrm{H}, \mathrm{ArH}), 7.17-7.18(\mathrm{~m}, 1 \mathrm{H}, \mathrm{ArH})$, $7.34(\mathrm{~d}, J=8.1 \mathrm{~Hz}, 1 \mathrm{H}, \mathrm{ArH}), 7.59(\mathrm{~d}, J=7.8 \mathrm{~Hz}, 1 \mathrm{H}, \mathrm{ArH}), 7.84(\mathrm{~d}, J=8.8 \mathrm{~Hz}, 2 \mathrm{H}, 2 \times \mathrm{ArH}), 8.46$ $(\mathrm{t}, J=5.5 \mathrm{~Hz}, 1 \mathrm{H}, \mathrm{NH}), 10.81(\mathrm{~s}, 1 \mathrm{H}, \mathrm{NH}) ;{ }^{13} \mathrm{C}-\mathrm{NMR}\left(\mathrm{DMSO}-d_{6}\right) \delta 25.21,40.06,55.21,111.26,111.88$, 113.32, 118.10, 118.21, 120.80, 122.46, 126.85, 127.19, 128.82, 136.14, 161.31, 165.49 ppm. HRMS $\left(\mathrm{HESI}^{+}\right)$: $[\mathrm{M}+\mathrm{H}]^{+}$: calculated for $\mathrm{C}_{18} \mathrm{H}_{19} \mathrm{~N}_{2} \mathrm{O}_{2}{ }^{+}(m / z)$ : 295.1441; found: 295.1436 .

$\mathrm{N}$-(2-(1H-Indol-3-yl)ethyl)-4-chlorobenzamide (17). Compound 1 was treated with 4-chlorobenzoyl chloride (5) according to the above procedure A to give the desired product $\mathbf{1 7}$ in the form of a white crystals $(66 \%)$; m.p.: $150.6-152.0^{\circ} \mathrm{C} .{ }^{1} \mathrm{H}-\mathrm{NMR}\left(\mathrm{DMSO}-d_{6}\right) \delta 2.95\left(\mathrm{t}, J=7.5 \mathrm{~Hz}, 2 \mathrm{H}, \mathrm{CH}_{2}\right), 3.52-3.57$ $\left(\mathrm{m}, 2 \mathrm{H}, \mathrm{CH}_{2}\right), 6.96-7.00(\mathrm{~m}, 1 \mathrm{H}, \mathrm{ArH}), 7.05-7.08(\mathrm{~m}, 1 \mathrm{H}, \mathrm{ArH}), 7.17-7.19(\mathrm{~m}, 1 \mathrm{H}, \mathrm{ArH}), 7.34(\mathrm{~d}, J=8.1 \mathrm{~Hz}$, $1 \mathrm{H}, \mathrm{ArH}), 7.54(\mathrm{~d}, J=8.6 \mathrm{~Hz}, 2 \mathrm{H}, 2 \times \mathrm{ArH}), 7.58(\mathrm{~d}, J=7.8 \mathrm{~Hz}, 1 \mathrm{H}, \mathrm{ArH}), 7.87(\mathrm{~d}, J=8.6 \mathrm{~Hz}, 2 \mathrm{H}$, $2 \times \mathrm{ArH}), 8.69(\mathrm{t}, J=5.6 \mathrm{~Hz}, 1 \mathrm{H}, \mathrm{NH}), 10.81(\mathrm{~s}, 1 \mathrm{H}, \mathrm{NH}) ;{ }^{13} \mathrm{C}-\mathrm{NMR}$ (DMSO- $\left.d_{6}\right) \delta 25.01,40.19,111.27$, $111.73,118.12,118.16,120.81,122.52,127.16,128.22,128.97,133.32,135.74,136.14,164.94$ ppm. HRMS $\left(\mathrm{HESI}^{+}\right)$: $[\mathrm{M}+\mathrm{H}]^{+}$: calculated for $\mathrm{C}_{17} \mathrm{H}_{16} \mathrm{ClN}_{2} \mathrm{O}^{+}(\mathrm{m} / z)$ : 299.0946; found: 299.0941 .

$\mathrm{N}$-(2-(1H-Indol-3-yl)ethyl)-3,4-dichlorobenzamide (18). Compound 1 was treated with 3,4-dichlorobenzoyl chloride (6) according to the above procedure A to give the desired product 18 in the form of a white crystals (75\%); m.p.: $112.4-113.9^{\circ} \mathrm{C} .{ }^{1} \mathrm{H}-\mathrm{NMR}$ (DMSO- $\left.d_{6}\right) \delta 2.96\left(\mathrm{t}, J=7.4 \mathrm{~Hz}, 2 \mathrm{H}, \mathrm{CH}_{2}\right), 3.53-3.57(\mathrm{~m}$, 2H, $\left.\mathrm{CH}_{2}\right), 6.96-7.00(\mathrm{~m}, 1 \mathrm{H}, \mathrm{ArH}), 7.05-7.08(\mathrm{~m}, 1 \mathrm{H}, \mathrm{ArH}), 7.18-7.19(\mathrm{~m}, 1 \mathrm{H}, \mathrm{ArH}), 7.34(\mathrm{~d}, J=8.1 \mathrm{~Hz}$, $1 \mathrm{H}, \mathrm{ArH}), 7.57(\mathrm{~d}, J=7.9 \mathrm{~Hz}, 1 \mathrm{H}, \mathrm{ArH}), 7.75(\mathrm{~d}, J=8.4 \mathrm{~Hz}, 1 \mathrm{H}, \mathrm{ArH}), 7.83(\mathrm{dd}, J=2.1,8.4 \mathrm{~Hz}, 1 \mathrm{H}, \mathrm{ArH})$, $8.07(\mathrm{~d}, J=2.0 \mathrm{~Hz}, 1 \mathrm{H}, \mathrm{ArH}), 8.80(\mathrm{t}, J=5.5 \mathrm{~Hz}, 1 \mathrm{H}, \mathrm{NH}), 10.82(\mathrm{~s}, 1 \mathrm{H}, \mathrm{NH}) ;{ }^{13} \mathrm{C}-\mathrm{NMR}\left(\mathrm{DMSO}-d_{6}\right) \delta 24.88$, 40.32, 111.29, 111.64, 118.13, 120.82, 122.57, 127.15, 127.38, 129.03, 130.56, 131.10, 133.74, 134.89, 136.14, 163.72 ppm. HRMS $\left(\mathrm{HESI}^{+}\right)$: $[\mathrm{M}+\mathrm{H}]^{+}$: calculated for $\mathrm{C}_{17} \mathrm{H}_{15} \mathrm{Cl}_{2} \mathrm{~N}_{2} \mathrm{O}^{+}(m / z)$ : 333.0556; found: 333.0553 .

N-(2-(1H-Indol-3-yl)ethyl)-2-naphthamide (19). Compound 1 was treated with 2-naphthoyl chloride (7) according to the above procedure $\mathrm{A}$ to give the desired product 19 in the form of a white crystals (92\%); m.p.: $193.2-195.0{ }^{\circ} \mathrm{C} .{ }^{1} \mathrm{H}-\mathrm{NMR}\left(\mathrm{DMSO}-d_{6}\right) \delta 3.02\left(\mathrm{t}, J=7.5 \mathrm{~Hz}, 2 \mathrm{H}, \mathrm{CH}_{2}\right), 3.61-3.65(\mathrm{~m}, 2 \mathrm{H}$, $\left.\mathrm{CH}_{2}\right), 6.98-7.02(\mathrm{~m}, 1 \mathrm{H}, \mathrm{ArH}), 7.07-7.10(\mathrm{~m}, 1 \mathrm{H}, \mathrm{ArH}), 7.22-7.24(\mathrm{~m}, 1 \mathrm{H}, \mathrm{ArH}), 7.36(\mathrm{~d}, J=8.1 \mathrm{~Hz}, 1 \mathrm{H}$, $\mathrm{ArH}), 7.57-7.64(\mathrm{~m}, 3 \mathrm{H}, 3 \times \mathrm{ArH}), 7.95-8.03(\mathrm{~m}, 4 \mathrm{H}, 4 \times \mathrm{ArH}), 8.47(\mathrm{~s}, 1 \mathrm{H}, \mathrm{ArH}), 8.80(\mathrm{t}, J=5.6 \mathrm{~Hz}$, $1 \mathrm{H}, \mathrm{NH}), 10.84(\mathrm{~s}, 1 \mathrm{H}, \mathrm{NH}) ;{ }^{13} \mathrm{C}-\mathrm{NMR}\left(\mathrm{DMSO}-d_{6}\right) \delta 25.15,40.28,111.30,111.85,118.15,118.24,120.84$, 122.55, 124.10, 126.59, 127.25, 127.40, 127.52, 127.73, 128.70, 132.00, 132.08, 133.97, 136.17, 166.09 ppm. HRMS $\left(\mathrm{HESI}^{+}\right)$: $[\mathrm{M}+\mathrm{H}]^{+}$: calculated for $\mathrm{C}_{21} \mathrm{H}_{19} \mathrm{~N}_{2} \mathrm{O}^{+}(\mathrm{m} / \mathrm{z})$ : 315.1492; found: 315.1487 . 
N-(2-(1H-Indol-3-yl)ethyl)cyclohexanecarboxamide (20). Compound 1 was treated with cyclohexanecarbonyl chloride (8) according to the above procedure A to give the desired product 20 in the form of a white crystals (59\%); m.p.: 104.8-106.3 ${ }^{\circ} \mathrm{C} .{ }^{1} \mathrm{H}-\mathrm{NMR}\left(\mathrm{DMSO}-d_{6}\right) \delta 1.12-1.24\left(\mathrm{~m}, 4 \mathrm{H}, 2 \times \mathrm{CH}_{2}\right), 1.29-1.37$ $\left(\mathrm{m}, 2 \mathrm{H}, \mathrm{CH}_{2}\right), 1.65-1.71\left(\mathrm{~m}, 4 \mathrm{H}, 2 \times \mathrm{CH}_{2}\right), 2.04-2.10(\mathrm{~m}, 1 \mathrm{H}, \mathrm{CH}), 2.80\left(\mathrm{t}, J=7.4 \mathrm{~Hz}, 2 \mathrm{H}, \mathrm{CH}_{2}\right)$,

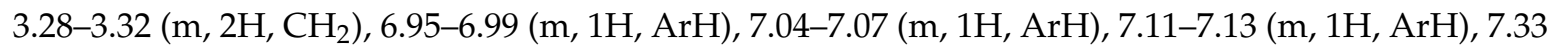
$(\mathrm{d}, J=8.1 \mathrm{~Hz}, 1 \mathrm{H}, \mathrm{ArH}), 7.53(\mathrm{~d}, J=7.8 \mathrm{~Hz}, 1 \mathrm{H}, \mathrm{ArH}), 7.76(\mathrm{t}, J=5.5 \mathrm{~Hz}, 1 \mathrm{H}, \mathrm{NH}), 10.78(\mathrm{~s}, 1 \mathrm{H}, \mathrm{NH})$; ${ }^{13}$ C-NMR (DMSO- $\left.d_{6}\right) \delta$ 25.14, 25.22, 25.41, 29.16, 39.19, 43.96, 111.21, 111.80, 118.03, 118.15, 120.75, $122.44,127.15,136.11,174.90$ ppm. HRMS $\left(\mathrm{HESI}^{+}\right)$: $[\mathrm{M}+\mathrm{H}]^{+}$: calculated for $\mathrm{C}_{17} \mathrm{H}_{23} \mathrm{~N}_{2} \mathrm{O}^{+}(\mathrm{m} / z)$ : 271.1805; found: 271.1799 .

N-(2-(1H-Indol-3-yl)ethyl)-1-naphthamide (21). Compound 1 was treated with 1-naphthoyl chloride (9) according to the above procedure A to give the desired product 21 in the form of a white crystals (80\%); m.p.: $164.5-166.5^{\circ} \mathrm{C} .{ }^{1} \mathrm{H}-\mathrm{NMR}\left(\mathrm{DMSO}-\mathrm{d}_{6}\right) \delta 3.04\left(\mathrm{t}, J=7.4 \mathrm{~Hz}, 2 \mathrm{H}, \mathrm{CH}_{2}\right), 3.63-3.67\left(\mathrm{~m}, 2 \mathrm{H}, \mathrm{CH}_{2}\right)$, 7.00-7.03 (m, 1H, ArH), 7.08-7.11 (m, 1H, ArH), 7.24-7.26 (m, 1H, ArH), 7.38 (d, J = 8.1 Hz, 1H, ArH), 7.51-7.57 (m, 4H, $4 \times \mathrm{ArH}), 7.64(\mathrm{~d}, J=7.8 \mathrm{~Hz}, 1 \mathrm{H}, \mathrm{ArH}), 7.95-8.00(\mathrm{~m}, 2 \mathrm{H}, 2 \times \mathrm{ArH}), 8.14-8.16(\mathrm{~m}, 1 \mathrm{H}$, $\mathrm{ArH}), 8.64(\mathrm{t}, J=5.6 \mathrm{~Hz}, 1 \mathrm{H}, \mathrm{NH}), 10.87(\mathrm{~s}, 1 \mathrm{H}, \mathrm{NH}) ;{ }^{13} \mathrm{C}-\mathrm{NMR}\left(\mathrm{DMSO}-d_{6}\right) \delta 25.06,39.93,111.30,111.74$, $118.15,118.26,120.84,122.70,124.85,124.87,125.41,126.06,126.48,127.24,128.03,129.48,129.66,133.01$, 135.09, 136.20, 168.39 ppm. HRMS $\left(\mathrm{HESI}^{+}\right)$: $[\mathrm{M}+\mathrm{H}]^{+}$: calculated for $\mathrm{C}_{21} \mathrm{H}_{19} \mathrm{~N}_{2} \mathrm{O}^{+}(\mathrm{m} / z)$ : 315.1492; found: 315.1486 .

3.4.2. General Procedure for Synthesis of Compounds 22-25 by Reaction of Commercially Available Carboxylic Acids with Tryptamine (Procedure B)

To the solution of carboxylic acid 10-13 (2.43 mM) in dry $\mathrm{CH}_{2} \mathrm{Cl}_{2}(5.5 \mathrm{~mL})$ that had been pre-cooled to $0{ }^{\circ} \mathrm{C}$, were gradually added the catalytic amount of DMF (1-2 drop) and oxalyl chloride (7.29 mM). The resulting mixture was stirred for $5 \mathrm{~min}$ at $0{ }^{\circ} \mathrm{C}$ and then at room temperature for a further $55 \mathrm{~min}$. Subsequently the solvent was evaporated under vacuum and the crude product was used further.

To solution of tryptamine $(1,1.87 \mathrm{mM})$ in dry $\mathrm{CH}_{2} \mathrm{Cl}_{2}(5 \mathrm{~mL})$ were gradually added at $0{ }^{\circ} \mathrm{C}$ the $\mathrm{Et}_{3} \mathrm{~N}(3.74 \mathrm{mM})$ and solution of crude product in dry $\mathrm{CH}_{2} \mathrm{Cl}_{2}(3 \mathrm{~mL})$. The resulting mixture was stirred for $10 \mathrm{~min}$ at $0{ }^{\circ} \mathrm{C}$ and then at room temperature for a further $50 \mathrm{~min}$. Subsequently the solvent was evaporated under vacuum and the residue was chromatographed on silica gel, using heptane-EtOAc (2:1) as eluent.

N-(2-(1H-Indol-3-yl)ethyl)-1,2,3,4-tetrahydronaphthalene-2-carboxamide (22). Product 22 was prepared from 1,2,3,4-tetrahydro-2-naphthoic acid (10) according to the above procedure B in the form of a white crystals (81\%); m.p.: $123.2-125.2{ }^{\circ} \mathrm{C} .{ }^{1} \mathrm{H}-\mathrm{NMR}\left(\mathrm{DMSO}-d_{6}\right) \delta 1.64-1.73(\mathrm{~m}, 1 \mathrm{H}, \mathrm{CH}), 1.91-1.95$ $(\mathrm{m}, 1 \mathrm{H}, \mathrm{CH}), 2.46-2.49(\mathrm{~m}, 1 \mathrm{H}, \mathrm{CH}), 2.69-2.87\left(\mathrm{~m}, 6 \mathrm{H}, 3 \times \mathrm{CH}_{2}\right), 3.35-3.40\left(\mathrm{~m}, 2 \mathrm{H}, \mathrm{CH}_{2}\right), 6.97-7.00(\mathrm{~m}$, 1H, ArH), 7.04-7.09 (m, 5H, $5 \times \mathrm{ArH}), 7.15-7.17(\mathrm{~m}, 1 \mathrm{H}, \mathrm{ArH}), 7.35(\mathrm{~d}, J=8.1 \mathrm{~Hz}, 1 \mathrm{H}, \mathrm{ArH}), 7.56(\mathrm{~d}$, $J=7.9 \mathrm{~Hz}, 1 \mathrm{H}, \mathrm{ArH}), 7.99(\mathrm{t}, J=5.6 \mathrm{~Hz}, 1 \mathrm{H}, \mathrm{NH}), 10.81(\mathrm{~s}, 1 \mathrm{H}, \mathrm{NH}) ;{ }^{13} \mathrm{C}-\mathrm{NMR}\left(\mathrm{DMSO}-d_{6}\right) \delta 25.16,26.21$, 28.13, 31.77, 39.39, 40.33, 111.24, 111.77, 118.07, 118.18, 120.78, 122.53, 125.41, 125.43, 127.18, 128.46, $128.71,135.46,135.54,136.13,174.35 \mathrm{ppm}$. HRMS $\left(\mathrm{HESI}^{+}\right):[\mathrm{M}+\mathrm{H}]^{+}$: calculated for $\mathrm{C}_{21} \mathrm{H}_{23} \mathrm{~N}_{2} \mathrm{O}^{+}(\mathrm{m} / z)$ : 319.1805; found: 319.1800 .

N-(2-(1H-Indol-3-yl)ethyl)-5,6,7,8-tetrahydronaphthalene-2-carboxamide (23). Product 23 was prepared from 5,6,7,8-tetrahydro-2-naphthoic acid (11) according to the above procedure $\mathrm{B}$ in the form of a yellow-white crystals (91\%); m.p.: 137.0-139.0 ${ }^{\circ} \mathrm{C} .{ }^{1} \mathrm{H}-\mathrm{NMR}\left(\mathrm{DMSO}-d_{6}\right) \delta 1.72-1.76\left(\mathrm{~m}, 4 \mathrm{H}, 2 \times \mathrm{CH}_{2}\right)$, 2.71-2.78 (m, 4H, $\left.2 \times \mathrm{CH}_{2}\right), 2.93-2.96\left(\mathrm{~m}, 2 \mathrm{H}, \mathrm{CH}_{2}\right), 3.51-3.55\left(\mathrm{~m}, 2 \mathrm{H}, \mathrm{CH}_{2}\right), 6.97-7.00(\mathrm{~m}, 1 \mathrm{H}, \mathrm{ArH})$, 7.05-7.08 (m, 1H, ArH), $7.11(\mathrm{~d}, J=8.6 \mathrm{~Hz}, 1 \mathrm{H}, \mathrm{ArH}), 7.16-7.18(\mathrm{~m}, 1 \mathrm{H}, \mathrm{ArH}), 7.34(\mathrm{~d}, J=8.1 \mathrm{~Hz}, 1 \mathrm{H}$, $\mathrm{ArH}), 7.55-7.59(\mathrm{~m}, 3 \mathrm{H}, 3 \times \mathrm{ArH}), 8.46(\mathrm{t}, J=5.6 \mathrm{~Hz}, 1 \mathrm{H}, \mathrm{NH}), 10.80(\mathrm{~s}, 1 \mathrm{H}, \mathrm{NH}) ;{ }^{13} \mathrm{C}-\mathrm{NMR}\left(\mathrm{DMSO}-d_{6}\right)$ $\delta 22.42,22.51,25.14,28.63,28.70,40.03,111.25,111.86,118.09,118.20,120.79,122.45,124.11,127.20$, $127.68,128.62,131.80,136.13,136.31,139.79,166.03$ ppm. HRMS $\left(\mathrm{HESI}^{+}\right):[\mathrm{M}+\mathrm{H}]^{+}$: calculated for $\mathrm{C}_{21} \mathrm{H}_{23} \mathrm{~N}_{2} \mathrm{O}^{+}(\mathrm{m} / \mathrm{z})$ : 319.1805; found: 319.1802 . 
N-(2-(1H-Indol-3-yl)ethyl)cycloheptanecarboxamide (24). Product 24 was prepared from cycloheptanecarboxylic acid (12) according to the above procedure B in the form of a yellow-white crystals (90\%); m.p.: 88.4-90.4 ${ }^{\circ} \mathrm{C}$. ${ }^{1} \mathrm{H}-\mathrm{NMR}\left(\mathrm{DMSO}-d_{6}\right) \delta 1.34-1.57\left(\mathrm{~m}, 8 \mathrm{H}, 4 \times \mathrm{CH}_{2}\right), 1.63-1.73\left(\mathrm{~m}, 4 \mathrm{H}, 2 \times \mathrm{CH}_{2}\right), 2.21-2.26(\mathrm{~m}, 1 \mathrm{H}, \mathrm{CH})$, $2.79\left(\mathrm{t}, J=7.4 \mathrm{~Hz}, 2 \mathrm{H}, \mathrm{CH}_{2}\right), 3.28-3.32\left(\mathrm{~m}, 2 \mathrm{H}, \mathrm{CH}_{2}\right), 6.95-6.99(\mathrm{~m}, 1 \mathrm{H}, \mathrm{ArH}), 7.04-7.07$ (m, 1H, ArH), $7.11-7.13(\mathrm{~m}, 1 \mathrm{H}, \mathrm{ArH}), 7.33(\mathrm{~d}, J=8.1 \mathrm{~Hz}, 1 \mathrm{H}, \mathrm{ArH}), 7.53(\mathrm{~d}, J=7.8 \mathrm{~Hz}, 1 \mathrm{H}, \mathrm{ArH}), 7.75(\mathrm{t}, J=5.6 \mathrm{~Hz}$, $1 \mathrm{H}, \mathrm{NH}), 10.78(\mathrm{~s}, 1 \mathrm{H}, \mathrm{NH}) ;{ }^{13} \mathrm{C}-\mathrm{NMR}\left(\mathrm{DMSO}-d_{6}\right) \delta 25.15,26.05,27.83,31.09,39.18,45.55,111.21,111.81$, 118.03, 118.16, 120.75, 122.42, 127.15, 136.11, 176.01 ppm. HRMS (HESI $\left.{ }^{+}\right):[\mathrm{M}+\mathrm{H}]^{+}$: calculated for $\mathrm{C}_{18} \mathrm{H}_{25} \mathrm{~N}_{2} \mathrm{O}^{+}(m / z)$ : 285.1961; found: 285.1958 .

N-(2-(1H-Indol-3-yl)ethyl)-4-methylpentanamide (25). Product 25 was prepared from 4-methylpentanoic acid (13) according to the above procedure B in the form of a brown crystals (87\%); m.p.: 45.1-47.1 ${ }^{\circ} \mathrm{C}$. ${ }^{1} \mathrm{H}-\mathrm{NMR}\left(\mathrm{DMSO}-\mathrm{d}_{6}\right) \delta 0.85\left(\mathrm{~d}, J=6.6 \mathrm{~Hz}, 6 \mathrm{H}, 2 \times \mathrm{CH}_{3}\right), 1.37-1.41\left(\mathrm{~m}, 2 \mathrm{H}, \mathrm{CH}_{2}\right), 1.44-1.52(\mathrm{~m}, 1 \mathrm{H}, \mathrm{CH})$, 2.05-2.08 (m, 2H, CH $), 2.80\left(\mathrm{t}, J=7.4 \mathrm{~Hz}, 2 \mathrm{H}, \mathrm{CH}_{2}\right), 3.30-3.34\left(\mathrm{~m}, 2 \mathrm{H}, \mathrm{CH}_{2}\right), 6.96-6.99(\mathrm{~m}, 1 \mathrm{H}, \mathrm{ArH})$, 7.04-7.08 (m, 1H, ArH), 7.12-7.14 (m,1H, ArH), $7.33(\mathrm{~d}, J=8.1 \mathrm{~Hz}, 1 \mathrm{H}, \mathrm{ArH}), 7.53(\mathrm{~d}, J=7.8 \mathrm{~Hz}, 1 \mathrm{H}$, $\mathrm{ArH}), 7.88(\mathrm{t}, J=5.5 \mathrm{~Hz}, 1 \mathrm{H}, \mathrm{NH}), 10.80(\mathrm{~s}, 1 \mathrm{H}, \mathrm{NH}) ;{ }^{13} \mathrm{C}-\mathrm{NMR}\left(\mathrm{DMSO}-d_{6}\right) \delta 22.20,25.16,27.11,33.44$, $34.25,39.32,111.22,111.79,118.06,118.14,120.76,122.45,127.14,136.12,172.02$ ppm. HRMS (HESI $\left.{ }^{+}\right)$: $[\mathrm{M}+\mathrm{H}]^{+}$: calculated for $\mathrm{C}_{16} \mathrm{H}_{23} \mathrm{~N}_{2} \mathrm{O}^{+}(\mathrm{m} / z)$ : 259.1805 ; found: 259.1803 .

\subsection{In Vitro hTLR4/MD2 Activity Assessment}

Aliquots of $20 \mu \mathrm{L}$ of each compound was added into the well containing 25000 HEK-Blue ${ }^{\text {TM }}-h$ TLR4 cells (Invivogen, Toulouse, France) and the final concentration of compound in each well was $10 \mu \mathrm{M}$. Each concentration was evaluated in triplicate. Synthetic MPLAs (Invivogen) of the same concentration was used as positive control, apyrogenous saline F1 (BBraun, Prague, Czech Republic) was used as negative control. Plates were incubated overnight for $16 \mathrm{~h}$ at $37{ }^{\circ} \mathrm{C} 5 \% \mathrm{CO}_{2}$. After the incubation $20 \mu \mathrm{L}$ aliquots of supernatant were collected and mixed with $200 \mu \mathrm{L}$ of SEAP detection media (QuantiBlue ${ }^{\mathrm{TM}}$, Invivogen) and incubated for $2 \mathrm{~h}$ at $37{ }^{\circ} \mathrm{C} 5 \% \mathrm{CO}_{2}$. Absorbance of the solution was measured at $630 \mathrm{~nm}$ and activity of each compound expressed as a percentage of an activity of the MPLA of respective concentration was determined $(n=3)$.

\subsection{Surface Plasmon Resonance Spectroscopy}

Surface plasmon resonance (SPR) experiments methodology was adapted from experiments by Svajger et al. [32]. The experiments were performed using a Biacore T200 (GE Healthcare, Little Chalfont, UK) instrument equipped with a Series S-CM5 sensor chip (GE Healthcare). Dulbecco's PBS supplied with 0.05\% tween 20 and DMSO was used for immobilization of the protein. Recombinant human $h$ TLR4/MD2 (R\&D Systems, Minneapolis, MN, USA) was attached to the surface of the chip by amine coupling. The surface of flow cells 1 and 2 was initially activated with a 10-min pulse of a 1:1 mixture of 0.4 M 1-ethyl-3-(3-dimethylaminopropyl)-carbodiimide hydrochloride and 0.1 $\mathrm{M} N$-hydroxysuccinimide, according to manufacturer recommendations. TLR4 was diluted into $10 \mathrm{mM}$ sodium acetate buffer, $\mathrm{pH} 5.5$, to a final concentration of $200 \mu \mathrm{g} / \mathrm{mL}$, and injected twice for $600 \mathrm{~s}$ over the second flow cell. Both flow cells were blocked with a 10-min pulse of $1.0 \mathrm{M}$ ethanolamine $\mathrm{pH} 8.5$. The final capacity level was about $8000 \mathrm{RU}$. Analysis was performad in the running buffer consisting of Dulbecco's PBS (10 mM Na${ }_{2} \mathrm{HPO}_{4}, 2$ mM KH $\mathrm{PO}_{4}, 137 \mathrm{mM} \mathrm{NaCl}, 2 \mathrm{mM} \mathrm{KCl}$, pH 7.4) supplemented with 1\% DMSO (Sigma Aldrich, Darmstadt, Germany) and 1\% as. All of the three hits from the cell-based assays were tested at two different concentrations: $20 \mu \mathrm{M}$ and $200 \mu \mathrm{M}$. Each compound was injected for $1 \mathrm{~min}$ at a flow-rate of $30 \mu \mathrm{L} / \mathrm{min}$, and the dissociation was monitored for $30 \mathrm{~s}$. Regeneration was not needed, although $30 \mathrm{~s}$ of buffer-flow was used to stabilize the surface after each injection. We compared the responses obtained by the injections of the buffer and the two different sample concentrations, and continued the study with the compound that showed binding. We used the following concentrations for titration: $0,6.25,12.5,25,50,100$ and $200 \mu \mathrm{M}$. 


\subsection{Cytotoxicity}

Standard MTT assay (Sigma Aldrich, Darmstadt, Germany) was applied according to the manufacturer's protocol on the CHO-K1 (Chinese hamster ovary, ECACC, Salisbury, UK) in order to compare the effect of different compound within the series. The cells were cultured according to ECACC recommended conditions and seeded in a density of 8000 per well. Briefly, tested compounds were dissolved in DMSO (Sigma Aldrich, Darmstadt, Germany) and subsequently in the growth medium (F-12) so that the final concentration of DMSO did not exceed $0.5 \%(v / v)$ per well. Cells were exposed to the tested compounds for $24 \mathrm{~h}$. Then the medium was replaced by a medium containing $10 \mu \mathrm{M}$ of MTT and cells were allowed to produce formazan for another approximately $3 \mathrm{~h}$ under surveillance. Thereafter, medium with MTT was sucked out and crystals of formazan were dissolved in DMSO $(100 \mu \mathrm{L})$. Cell viability was assessed spectrophotometrically by the amount of formazan produced. Absorbance was measured at $570 \mathrm{~nm}$ with $650 \mathrm{~nm}$ reference wavelength on Synergy HT (BioTek, Winooski, VT, USA). IC 50 was then calculated from the control—subtracted triplicates using non-linear regression (four parameters) of GraphPad Prism 5 software (GraphPad Software, La Jolla, CA, USA). Final $\mathrm{IC}_{50}$ and SEM value was obtained as a mean of 2-3 independent measurements.

\subsection{Ex Vivo-IL-6 Production}

PBMCs was obtained by standard protocol [33] using Histopaque 1077 gradient from whole blood of healthy donors. Cells were seeded at 25,000 cells per well and incubated for $24 \mathrm{~h}$ with final concentration $10 \mu \mathrm{M}$ of each compound in triplicate $(n=3)$. After $24 \mathrm{~h} 100 \mu \mathrm{L}$ of supernatant was collected from each well and level of IL-6 was determined by human IL-6 ELISA kit obtained from Sigma Aldrich (Darmstadt, Germany). Absorbance was measured at $450 \mathrm{~nm}$ wavelength on Synergy HT (BioTek). Level of IL-6 was calculated from standard curve using RIA nonlinear plot in Graph Pad Prism 6.

\section{Conclusions}

This study reveals a new group of small-molecule ligands, designed by an in silico approach, that possess intrinsic agonistic activity on the $h$ TLR4/MD2 and by that represent potential vaccine adjuvants. Although the observed in vitro and ex vivo immunostimulation potency is not as strong as in works of Chan et al. [17], or Jiang et al. [34], but it must be noted, that ours compounds are structurally far more distant from Lipid A and LPS and contain neither "fatty" part of LPS molecule, nor even single long lipidic chain at all. Recent thinking was that for $h$ TLR4/MD2 binding at least three long acyl chains (C8-C18) is necessary to be present in the molecule to elicit the agonistic effect [9]. The direct binding of the best in vitro compound (17) to the $h$ TLR4/MD2 receptor was confirmed by SPR study, however, this compound failed to produce IL-6 in the ex vivo study using PBMCs. On the other hand compounds $\mathbf{1 4}$ and 22 succeeded in this task despite of the low in vitro activity. Interestingly, high potential of 22 was suggested by in sillico studies. Therefore, further study evaluating the influence of novel compounds on Th1/Th2/Th17 bias will be needed to thoroughly assess their adjuvant and immunomodulating potential. As well as address inconsistency found among in silico, in vitro and ex vivo findings. Even though 17 did not elicit production of IL-6, compounds 14 and 22 succeeded in this task. Notably to say, all the compounds show very low cytotoxicity with $\mathrm{IC}_{50}$ ranging from $98 \mu \mathrm{M}$ to $892 \mu \mathrm{M}$. Despite of found discrepancies we believe that by applying methods of rational drug design, we have found a novel class of TLR4 agonists which and therefore they might be regarded as novel class of potential $h$ TLR4/MD2-targeting adjuvants.

Supplementary Materials: Supplementary materials are available online. Figures (S14-S25) representing overlaid conformation of each ligand (14-25) in MD study; Video 1-Record of 10 ns MD simulation of 17.

Acknowledgments: This work was supported by Czech Science Foundation Grant No. 15-11776S, OU development plan IRP 1429, The Ministry of Education, Youth and Sports from the Large Infrastructures for Research, Experimental Development and Innovations project "IT4Innovations National Supercomputing Center-LM2015070". Access to the computing and storage facilities owned by parties and projects contributing to 
the National Grid Infrastructure "MetaCentrum" provided under the programme "Projects of Large Research, Development, and Innovations Infrastructures" (CESNET LM2015042), is greatly appreciated. We would also like to thank Josef Houser, from CEITEC Brno for help with the Interpretation of the SPR experiment.

Author Contributions: J.H., R.D., R.P. and K.K. conceived and designed the project. R.D., J.S.F.D.d.A. and T.C.C.F. designed and performed in silico experiment and wrote the corresponding part of the article. J.H. performed the in vitro and ex vivo immunologic and SPR experiments and wrote the corresponding parts of the manuscript. D.M. was responsible for synthetic part of the project. O.S. and M.B. performed cytotoxicity assays and O.S. evaluated cytotoxicity data. J.H. and O.S. finalized the paper.

Conflicts of Interest: The authors declare no conflict of interest. The founding sponsors had no role in the design of the study; in the collection, analyses, or interpretation of data; in the writing of the manuscript, and in the decision to publish the results.

\section{References}

1. Lo, N.C.; Hotez, P.J. Public Health and Economic Consequences of Vaccine Hesitancy for Measles in the United States. JAMA Pediatr. 2017, 171, 887-892. [CrossRef] [PubMed]

2. Calandrillo, S.P. Vanishing vaccinations: Why are so many Americans opting out of vaccinating their children? Univ. Mich. J. Law Reform 2004, 37, 353-440. [PubMed]

3. Freeman, M. Toxic Vaccine Adjuvants \& Ingredients: The Top 10. Available online: http:/ / freedom-articles. toolsforfreedom.com/toxic-vaccine-adjuvants-the-top-10/ (accessed on 5 October 2017).

4. Kocourkova, A.; Honegr, J.; Kuca, K.; Danova, J. Vaccine ingredients: Components that influence vaccine efficacy. Mini-Rev. Med. Chem. 2017, 17, 451-466. [CrossRef] [PubMed]

5. Doja, A.; Roberts, W. Immunizations and autism: A review of the literature. Can. J. Neurol. Sci. 2006, 33, 341-346. [CrossRef] [PubMed]

6. C-621/15-N. W and Others v Sanofi Pasteur MSD and Others; Court of Justice of the European Union: Luxemburg, 21 June 2017.

7. O'Hagan, D.T. Vaccine Adjuvants: Preparation Methods and Research Protocols; Humana Press: New York, NY, USA, 2000.

8. $\quad$ Ainge, G.D.; Martin, W.J.; Compton, B.J.; Hayman, C.M.; Larsen, D.S.; Yoon, S.I.; Wilson, I.A.; Harper, J.L.; Painter, G.F. Synthesis and Toll-like Receptor 4 (TLR4) Activity of Phosphatidylinositol Dimannoside Analogues. J. Med. Chem. 2011, 54, 7268-7279. [CrossRef] [PubMed]

9. Honegr, J.; Soukup, O.; Dolezal, R.; Malinak, D.; Penhaker, M.; Prymula, R.; Kuca, K. Structural Properties of Potential Synthetic Vaccine Adjuvants-TLR Agonists. Curr. Med. Chem. 2015, 22, 3306-3325. [CrossRef] [PubMed]

10. Wang, X.H.; Smith, C.; Yin, H. Targeting Toll-like receptors with small molecule agents. Chem. Soc. Rev. 2013, 42, 4859-4866. [CrossRef] [PubMed]

11. Dolezal, R.; Ramalho, T.; França, T.C.; Kuca, K. Parallel Flexible Molecular Docking in Computational Chemistry on High Performance Computing Clusters. In Computational Collective Intelligence; Núñez, M., Nguyen, N.T., Camacho, D., Trawiński, B., Eds.; Springer International Publishing: Cham, Switzerland, 2015; Volume 9330, pp. 418-427.

12. Zhang, S.T.; Cheng, K.; Wang, X.H.; Yin, H. Selection, synthesis, and anti-inflammatory evaluation of the arylidene malonate derivatives as TLR4 signaling inhibitors. Bioorg. Med. Chem. 2012, 20, 6073-6079. [CrossRef] [PubMed]

13. Weber, M.D.; Frank, M.G.; Sobesky, J.L.; Watkins, L.R.; Maier, S.F. Blocking toll-like receptor 2 and 4 signaling during a stressor prevents stress-induced priming of neuroinflammatory responses to a subsequent immune challenge. Brain Behav. Immun. 2013, 32, 112-121. [CrossRef] [PubMed]

14. Stover, A.G.; Correia, J.D.; Evans, J.T.; Cluff, C.W.; Elliott, M.W.; Jeffery, E.W.; Johnson, D.A.; Lacy, M.J.; Baldridge, J.R.; Probst, P.; et al. Structure-activity relationship of synthetic Toll-like receptor 4 agonists. J. Biol. Chem. 2004, 279, 4440-4449. [CrossRef] [PubMed]

15. Lewicky, J.D.; Ulanova, M.; Jiang, Z.H. Improving the immunostimulatory potency of diethanolamine-containing lipid A mimics. Bioorg. Med. Chem. 2013, 21, 2199-2209. [CrossRef] [PubMed] 
16. Lewicky, J.D.; Ulanova, M.; Jiang, Z.H. Synthesis of a dimeric monosaccharide lipid A mimic and its synergistic effect on the immunostimulatory activity of lipopolysaccharide. Carbohydr. Res. 2011, 346, 1705-1713. [CrossRef] [PubMed]

17. Chan, M.; Hayashi, T.; Mathewson, R.D.; Nour, A.; Hayashi, Y.; Yao, S.Y.; Tawatao, R.I.; Crain, B.; Tsigelny, I.F.; Kouznetsoya, V.L.; et al. Identification of Substituted Pyrimido 5,4-b indoles as Selective Toll-Like Receptor 4 Ligands. J. Med. Chem. 2013, 56, 4206-4223. [CrossRef] [PubMed]

18. Wu, G.; Lv, T.; Mo, W.; Yang, X.; Gao, Y.; Chen, H. One-pot synthesis of tricyclo-1, 4-benzoxazines via visible-light photoredox catalysis in continuous flow. Tetrahedron Lett. 2017, 58, 1395-1398. [CrossRef]

19. Li, Y.; Feng, T.; Liu, P.; Liu, C.; Wang, X.; Li, D.; Li, N.; Chen, M.; Xu, Y.; Si, S. Optimization of rutaecarpine as ABCA1 up-regulator for treating atherosclerosis. ACS Med. Chem. Lett. 2014, 5, 884-888. [CrossRef] [PubMed]

20. Stephens, M.D.; Hubble, V.B.; Ernst, R.K.; van Hoek, M.L.; Melander, R.J.; Cavanagh, J.; Melander, C. Potentiation of Francisella resistance to conventional antibiotics through small molecule adjuvants. MedChem Comm 2016, 7, 128-131. [CrossRef] [PubMed]

21. Yoshioka, T.; Mohri, K.; Oikawa, Y.; Yonemitsu, O. Synthesis of oxazolylindole alkaloids from tryptamine and tryptophan by oxidation with 2,3-dichloro-5,6-dicyanobenzoquinone. J. Chem. Res. 1981, 12, 194-195. [CrossRef]

22. Ho, B.T.; McIsaac, W.M.; Tansey, L.W. Hydroxyindole-O-methyltransferase III: Influence of the phenyl moiety on the inhibitory activities of some $\mathrm{N}$-acyltryptamines. J. Pharm. Sci. 1969, 58, 563-566. [CrossRef] [PubMed]

23. Wu, J.; Wang, F.; Ma, Y.; Cui, X.; Cun, L.; Zhu, J.; Deng, J.; Yu, B. Asymmetric transfer hydrogenation of imines and iminiums catalyzed by a water-soluble catalyst in water. Chem. Commun. 2006, 1766-1768. [CrossRef] [PubMed]

24. Ho, B.T.; McIssaac, W.M.; Tansey, L.W.; Kralik, P.M. Hydroxyindole-O-methyltransferase II. Inhibitory Activities of Some N-Acyltryptamines. J. Pharm. Sci. 1968, 57, 1998-2000. [CrossRef] [PubMed]

25. Ho, B.T.; An, R.; Noel, M.B.; Tansey, L.W. Central nervous system depressive activity of some amides of tryptamine. J. Med. Chem. 1971, 14, 553-554. [CrossRef] [PubMed]

26. Trott, O.; Olson, A.J. Software News and Update AutoDock Vina: Improving the Speed and Accuracy of Docking with a New Scoring Function, Efficient Optimization, and Multithreading. J. Comput. Chem. 2010, 31, 455-461. [PubMed]

27. Kumari, R.; Kumar, R.; Lynn, A. g_mmpbsa-A GROMACS Tool for High-Throughput MM-PBSA Calculations. J. Chem. Inf. Model. 2014, 54, 1951-1962. [CrossRef] [PubMed]

28. Baker, N.A.; Sept, D.; Joseph, S.; Holst, M.J.; McCammon, J.A. Electrostatics of nanosystems: Application to microtubules and the ribosome. Proc. Natl. Acad. Sci. USA 2001, 98, 10037-10041. [CrossRef] [PubMed]

29. Ohto, U.; Yamakawa, N.; Akashi-Takamura, S.; Miyake, K.; Shimizu, T. Structural Analyses of Human Toll-like Receptor 4 Polymorphisms D299G and T399I. J. Biol. Chem. 2012, 287, 40611-40617. [CrossRef] [PubMed]

30. Nocedal, J.; Wright, S.J. Numerical Optimization; Springer Series in Operations Research; Springer: New York, NY, USA, 1999.

31. Liu, B.; Wang, L.; Jin, Y.H. An effective PSO-based memetic algorithm for flow shop scheduling. IEEE Trans. Syst. Man Cybern. Part B Cybern. 2007, 37, 18-27. [CrossRef]

32. Svajger, U.; Brus, B.; Turk, S.; Sova, M.; Hodnik, V.; Anderluh, G.; Gobec, S. Novel toll-like receptor 4 (TLR4) antagonists identified by structure- and ligand-based virtual screening. Eur. J. Med. Chem. 2013, 70, 393-399. [CrossRef] [PubMed] 
33. Sigma-Aldrich, Histopaque 1077 Datasheet. Available online: https:/ / www.sigmaaldrich.com/content/dam/ sigma-aldrich/docs/Sigma/Product_Information_Sheet/1/10771pis.pdf (accessed on 6 December 2017).

34. Jiang, Z.H.; Budzynski, W.A.; Qiu, D.X.; Yalamati, D.; Koganty, R.R. Monophosphoryl lipid A analogues with varying 3-O-substitution: Synthesis and potent adjuvant activity. Carbohydr. Res. 2007, 342, 784-796. [CrossRef] [PubMed]

Sample Availability: Samples of the compounds 14, 15, 16, 17, 19, 20 and 22 are available from the authors, upon request, please take into a consideration that not all samples may be available on short notice. 